\title{
Upward transport into and within the Asian monsoon anticyclone as inferred from StratoClim trace gas observations
}

\author{
Marc von Hobe ${ }^{1}$, Felix Ploeger ${ }^{1,5}$, Paul Konopka ${ }^{1}$, Corinna Kloss ${ }^{1,2}$, Alexey Ulanowski ${ }^{3}$, Vladimir Yushkov ${ }^{3}$, \\ Fabrizio Ravegnani ${ }^{4}$, C. Michael Volk ${ }^{5}$, Laura L. Pan ${ }^{6}$, Shawn B. Honomichl ${ }^{6}$, Simone Tilmes ${ }^{6}$, Douglas E. Kinnison ${ }^{6}$, \\ Rolando R. Garcia ${ }^{6}$, and Jonathon S. Wright ${ }^{7}$ \\ ${ }^{1}$ Institute for Energy and Climate Research (IEK-7), Forschungszentrum Jülich GmbH, 52425 Jülich, Germany \\ ${ }^{2}$ Laboratoire de Physique et Chimie de l'Environnement et de l'Espace (LPC2E), Université d'Orléans, \\ CNRS, Orléans, France \\ ${ }^{3}$ Central Aerological Observatory, Dolgoprudnyi, Moscow Region, Russia \\ ${ }^{4}$ National Research Council - Institute for Atmospheric Sciences and Climate (ISAC-CNR), 40129 Bologna, Italy \\ ${ }^{5}$ Institute for Atmospheric and Environmental Research, University of Wuppertal, Wuppertal, Germany \\ ${ }^{6}$ National Center for Atmospheric Research (NCAR), Boulder, CO 80307, USA \\ ${ }^{7}$ Department of Earth System Science, Tsinghua University, Beijing 100084, China
}

Correspondence: Marc von Hobe (m.von.hobe@fz-juelich.de)

Received: 25 August 2020 - Discussion started: 1 September 2020

Revised: 15 December 2020 - Accepted: 17 December 2020 - Published: 29 January 2021

\begin{abstract}
Every year during the Asian summer monsoon season from about mid-June to early September, a stable anticyclonic circulation system forms over the Himalayas. This Asian summer monsoon (ASM) anticyclone has been shown to promote transport of air into the stratosphere from the Asian troposphere, which contains large amounts of anthropogenic pollutants. Essential details of Asian monsoon transport, such as the exact timescales of vertical transport, the role of convection in cross-tropopause exchange, and the main location and level of export from the confined anticyclone to the stratosphere are still not fully resolved. Recent airborne observations from campaigns near the ASM anticyclone edge and centre in 2016 and 2017, respectively, show a steady decrease in carbon monoxide (CO) and increase in ozone $\left(\mathrm{O}_{3}\right)$ with height starting from tropospheric values of around $100 \mathrm{ppb} \mathrm{CO}$ and $30-50 \mathrm{ppb} \mathrm{O}_{3}$ at about $365 \mathrm{~K}$ potential temperature. $\mathrm{CO}$ mixing ratios reach stratospheric background values below $\sim 25 \mathrm{ppb}$ at about $420 \mathrm{~K}$ and do not show a significant vertical gradient at higher levels, while ozone continues to increase throughout the altitude range of the aircraft measurements. Nitrous oxide $\left(\mathrm{N}_{2} \mathrm{O}\right)$ remains at or only marginally below its 2017 tropospheric mixing ratio of $333 \mathrm{ppb}$ up to about $400 \mathrm{~K}$, which is above the local tropopause. A decline in $\mathrm{N}_{2} \mathrm{O}$ mixing ratios that indicates
\end{abstract}

a significant contribution of stratospheric air is only visible above this level. Based on our observations, we draw the following picture of vertical transport and confinement in the ASM anticyclone: rapid convective uplift transports air to near $16 \mathrm{~km}$ in altitude, corresponding to potential temperatures up to about $370 \mathrm{~K}$. Although this main convective outflow layer extends above the level of zero radiative heating (LZRH), our observations of $\mathrm{CO}$ concentration show little to no evidence of convection actually penetrating the tropopause. Rather, further ascent occurs more slowly, consistent with isentropic vertical velocities of $0.7-1.5 \mathrm{~K} \mathrm{~d}^{-1}$. For the key tracers $\left(\mathrm{CO}, \mathrm{O}_{3}\right.$, and $\left.\mathrm{N}_{2} \mathrm{O}\right)$ in our study, none of which are subject to microphysical processes, neither the lapse rate tropopause (LRT) around $380 \mathrm{~K}$ nor the cold point tropopause (CPT) around $390 \mathrm{~K}$ marks a strong discontinuity in their profiles. Up to about 20 to $35 \mathrm{~K}$ above the LRT, isolation of air inside the ASM anticyclone prevents significant in-mixing of stratospheric air (throughout this text, the term in-mixing refers specifically to mixing processes that introduce stratospheric air into the predominantly tropospheric inner anticyclone). The observed changes in $\mathrm{CO}$ and $\mathrm{O}_{3}$ likely result from in situ chemical processing. Above about $420 \mathrm{~K}$, mixing processes become more significant and the air inside 
the anticyclone is exported vertically and horizontally into the surrounding stratosphere.

\section{Introduction}

The Asian summer monsoon (ASM) anticyclone is the dominant large-scale circulation system in the Northern Hemisphere (NH) summertime upper troposphere and lower stratosphere (UTLS) (e.g. Hoskins and Rodwell, 1995). Deep ASM convection drives vertical transport of boundary layer air to the UTLS, where the confinement of anticyclonic flow facilitates a persistent chemical signature that has been detected by multiple satellite sensors (Filipiak et al., 2005; Park et al., 2008, 2007; Randel and Park, 2006; Randel et al., 2010; Santee et al., 2017; Thomason and Vernier, 2013; Vernier et al., 2011). Randel et al. (2010) illustrated this troposphere-to-stratosphere transport using hydrogen cyanide ( $\mathrm{HCN})$, a tracer of anthropogenic pollution and biomass burning measured by ACE-FTS (Atmospheric Chemistry Experiment Fourier Transform Spectrometer, installed on the Canadian satellite SCISAT), and described the ASM anticyclone as a gateway for boundary layer air from one of the most polluted areas on Earth to enter the global stratosphere while bypassing the tropical tropopause.

These satellite observations, although effective in demonstrating the seasonal-average signature, do not have sufficient spatio-temporal resolution to clarify some of the key characteristics of this transport pathway. There are a number of outstanding questions regarding the role of ASM transport in connecting Asian boundary layer emissions and regional pollution to global tropospheric and stratospheric chemistry and to the ensuing perturbations in regional and global climate. These questions include the most efficient vertical transport locations and timescales; the dynamical processes driving these transport patterns; the respective roles of deep convection and large-scale radiatively balanced ascent; the dominant source regions for air masses that feed into the anticyclone; the extent of dynamical confinement within the anticyclone; the vertical and horizontal transport pathways of air masses exiting the anticyclone; and the quantitative impact of the ASM on stratospheric water vapour, ozone, and aerosols. These questions have been the focus of a large number of studies using chemical transport models, Lagrangian trajectory models, reanalysis products and observational data (e.g. Bergman et al., 2013; Fu et al., 2006; Lau et al., 2018; Li et al., 2005, 2020; Pan et al., 2016; Park et al., 2009; Ploeger et al., 2015, 2017; Vogel et al., 2015, 2019; Yan et al., 2019; Yu et al., 2017; Nützel et al., 2019).

Of particular interest to this study is a characteristic description of the ASM transport structure that has emerged from recent modelling studies (Bergman et al., 2013; Pan et al., 2016):
I. Although the chemical signature of uplifted tropospheric species fills the entire anticyclone in the seasonal-average view, deep vertical transport to the anticyclone level occurs primarily in a region in the southeastern quadrant of the anticyclone (consistent with the linearized model for off-equatorial convective forcing of tropical waves presented by Gill (1980), centred near the southern flank of the Tibetan Plateau and including the southern slope of the Himalayas, north-east India and Nepal, and the northern portion of the Bay of Bengal).

II. In this preferred uplift region, transport from the boundary layer to the tropopause level behaves like a "chimney", dominated by rapid ascent.

III. This behaviour changes at the upper troposphere (UT) level, where sub-seasonal dynamics drive east-west oscillations of the anticyclone. These 10 to $20 \mathrm{~d}$ oscillations mix the uplifted boundary layer air within the large-scale anticyclone and contribute to mixing of anticyclone air with the background, thus providing a pathway for this air to enter the global stratosphere.

The transport behaviour described in point II has been supported by an analysis using Modern-Era Retrospective analysis for Research and Applications, Version 2 (MERRA-2) assimilated trace gases and aerosols (Lau et al., 2018), where the peak monsoon-season aerosol transport is described as a "double-stem-chimney cloud" structure that extends from the boundary layer to around $16 \mathrm{~km}$, near the tropopause level. The "double-stem" rapid convective lofting is identified over two localized areas: the Himalayas-Gangetic Plain and the Sichuan Basin in southwestern China.

This rapid uplift is of special interest for ASM research, because the relatively short transport timescale makes this pathway an effective route for very-short-lived (VSL) ozonedepleting substances (ODSs) to reach the stratosphere. The level at which convectively driven transport transitions to wave-driven slow ascent is among the outstanding issues that must be addressed to further characterize this transport pathway and its effective timescale. Earlier studies often put this level at approximately $360 \mathrm{~K}$ potential temperature (e.g. Park et al., 2009) based on average tropical conditions. New satellite observations over the last decade indicate that the ASM region contains significantly deeper convection, indicated by higher frequencies of convective cloud tops above $380 \mathrm{~K}$ potential temperature (Ueyama et al., 2018).

Verification of the chimney-like behaviour suggested by model results requires detailed analysis of high-resolution airborne measurements. The StratoClim (Stratospheric and upper tropospheric processes for better climate predictions; http://www.stratoclim.org, last access: 21 January 2021) campaign using the stratospheric research aircraft M55 Geophysica is the first airborne campaign to provide data suitable for such verification. Based out of Kathmandu, Nepal, Stra- 
toClim conducted eight research flights in the central region of the ASM anticyclone in summer 2017.

In this work, we use airborne in situ measurements of carbon monoxide $(\mathrm{CO})$, ozone $\left(\mathrm{O}_{3}\right)$ and nitrous oxide $\left(\mathrm{N}_{2} \mathrm{O}\right)$ collected both outside and inside the ASM anticyclone, and here particularly in the vicinity of the chimney regions. We focus on these three trace gases because they provide complementary information on transport, mixing and processing. $\mathrm{CO}$ is a tropospheric tracer that is enhanced in polluted air and experiences photochemical removal in the UTLS with a lifetime of around 2 to 3 months, and it is thus a suitable tracer to investigate the vertical reach of deep convection. $\mathrm{O}_{3}$ is photochemically produced in the UTLS and above at rates as high as a few parts per billion (ppb) per day. Concentrations of $\mathrm{O}_{3}$ can reach parts per million (ppm) levels in the stratosphere but do not typically exceed a few tens of $\mathrm{ppb}$ in the troposphere, making it useful for examining the transition from tropospheric air to stratospheric air. $\mathrm{N}_{2} \mathrm{O}$ is a tropospheric tracer with a significantly longer photochemical lifetime than $\mathrm{CO}$, so the two tracers can be used together to infer transport timescales. $\mathrm{N}_{2} \mathrm{O}$ is removed only after substantial residence time within the stratosphere. Significant reductions in $\mathrm{N}_{2} \mathrm{O}$ mixing ratios thus indicate in-mixing of aged stratospheric air.

Using these three trace gases together with dynamical variables, we address the following questions:

- Q1. Does the vertical distribution of $\mathrm{CO}$ and $\mathrm{O}_{3}$ support the occurrence of rapid convective transport up to the tropopause level?

- Q2. At what potential temperature level does the timescale of transport change based on observed vertical gradients in the trace gas profiles?

- Q3. Where is this transition region located relative to the tropopause?

- Q4. At what level do we begin to see significant signatures of mixing with stratospheric air?

The flights and measurements are described in Sect. 2, which also introduces model tools and specific dynamical coordinates used in the analysis. Statistical analysis of the observations in terms of different horizontal and vertical coordinates and a comparison of observed and simulated $\mathrm{O}_{3}$ vs. $\mathrm{CO}$ tracer correlations are presented in Sect. 3, followed by detailed discussion of the results in the context of the four questions listed above in Sect. 4. In the concluding Sect. 5, we draw a summary picture of vertical transport and confinement inside the ASM anticyclone and compare this to other recent studies.

\section{Methods}

\subsection{Field campaigns}

Two airborne field campaigns utilizing the high-altitude aircraft M55 Geophysica were carried out under the umbrella of the EU project StratoClim. Three flights were conducted from Kalamata, Greece, between 30 August and 6 September 2016, and eight flights were conducted from Kathmandu, Nepal, between 27 July and 10 August 2017. Our study mainly adopts a statistical approach to analyse the entire observational data set comprising measurements from all flights. Figure 1 shows all flight tracks and their positions relative to the typical ASM anticyclone area for the two respective years determined using the criterion defined below in Sect. 2.3.2. The Kalamata base in 2016 was located outside the ASM anticyclone, and air inside or exported from the ASM anticyclone was only probed sporadically. The Kathmandu base in 2017 was located inside the ASM anticyclone region, and according to the criterion used (Sect. 2.3.2.), the bulk of the observations were made within the ASM anticyclone. A comprehensive campaign overview and descriptions of the purpose and specific meteorological situation for each flight are given by Stroh et al. (2021).

\subsection{Measurements, dynamical coordinates and analysis tools}

\subsubsection{Carbon monoxide (CO)}

Carbon monoxide was measured by the new AMICA (Airborne Mid Infrared Cavity enhanced Absorption spectrometer) instrument deployed for the first time during StratoClim. AMICA consists of a power module and a pressurized enclosure containing all major optical components and data acquisition hardware. The instrument is placed underneath a dome-shaped structure on top of the Geophysica aircraft, drawing air from a rear-facing inlet through a $2 \mathrm{~m}$ length of SilcoNert ${ }^{\circledR}$-coated stainless-steel tubing. It employs the ICOS (integrated cavity output spectroscopy; O'Keefe et al., 1999) technique to measure the trace gases carbonyl sulfide (OCS), carbon dioxide $\left(\mathrm{CO}_{2}\right)$, water vapour $\left(\mathrm{H}_{2} \mathrm{O}\right)$ and $\mathrm{CO}$ in the wavenumber range $2050.25-2051.1 \mathrm{~cm}^{-1}$. Full instrumental details will be given in a forthcoming paper (Kloss et al., 2021).

$\mathrm{CO}$ mixing ratios were retrieved from observed infrared (IR) spectra using a transition at $2050.90 \mathrm{~cm}^{-1}$ with line parameters taken from the HITRAN 2012 database (Rothman et al., 2013) and no further calibration parameters. The accuracy was cross-checked for a range of mixing ratios (30$5000 \mathrm{ppb}$ ) prepared from a $5 \pm 0.05 \mathrm{ppm} \mathrm{CO}$ standard (AirProducts) by dilution with nitrogen or argon (argon was used at the lowest mixing ratios, because the nitrogen gas bottle contained a CO impurity at a concentration of $\sim 30 \mathrm{ppb}$ ). Taking into account uncertainty in the standard and uncer- 

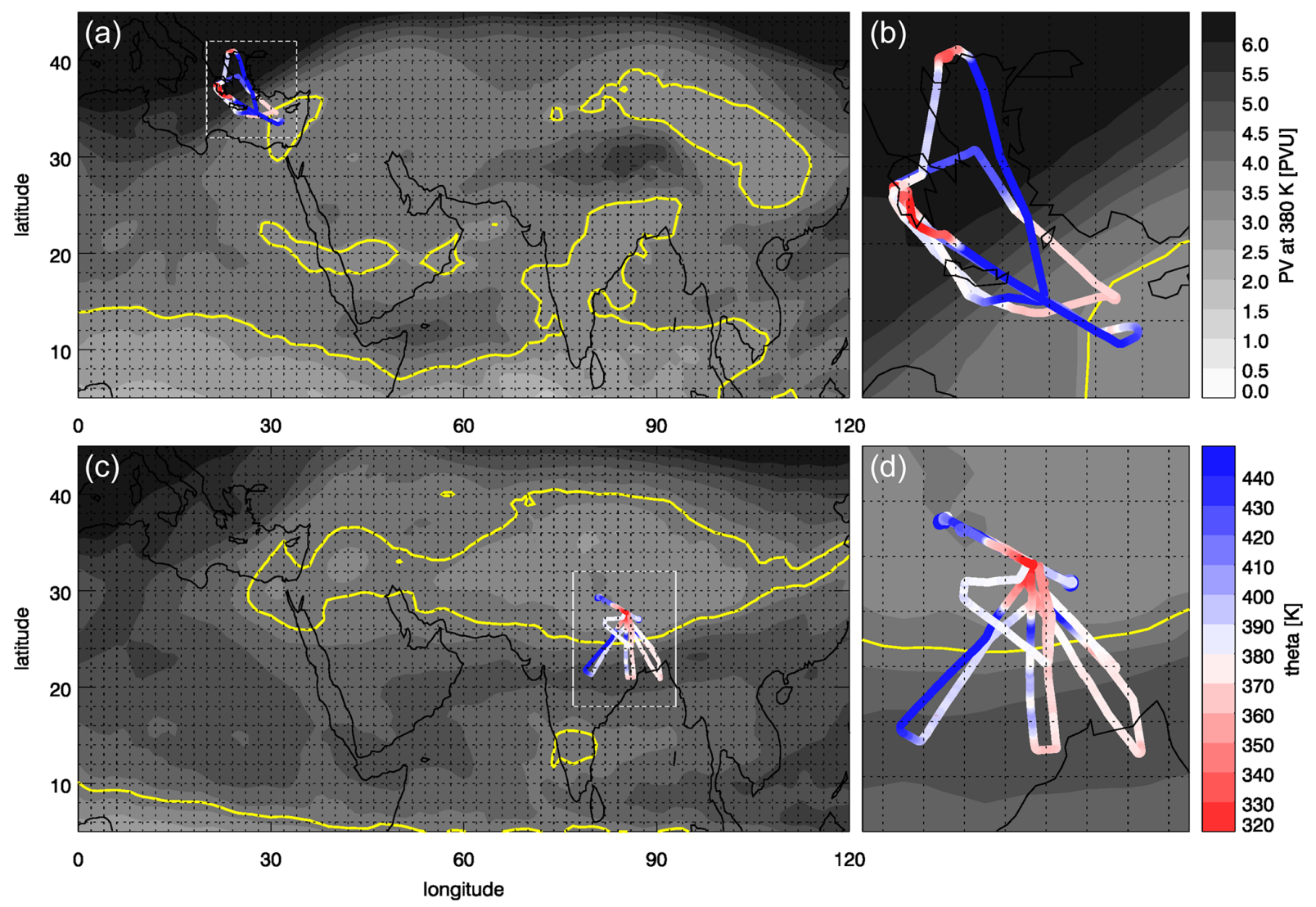

Figure 1. Maps showing tracks of all Geophysica flights conducted during the StratoClim campaign phases in 2016 (a, b) and 2017 (c, d) for the larger ASM area (a, c) and zoomed in to the respective campaign area (b, d). Potential vorticity (PV) contours (grey shadings), averaged between 29 August and 7 September 2016 and between 26 July and 11 August 2017, respectively, are shown for the 380 K potential temperature level, on which the Ploeger et al. (2015) criterion is applied to determine the average ASM anticyclone boundaries for the two campaign periods (yellow lines; PV thresholds were determined to be 3.5 PVU (potential vorticity unit) for 2016 and 3.7 PVU for 2017 ; maps of the average ASM anticyclone position for the full monsoon season, i.e. 1 July-31 August, are shown in the Supplement Fig. S4).

tainties in the mass flow controller (MFC) flows used to dilute it, the overall accuracy is estimated to be better than $5 \%$. For our analysis, we use AMICA CO data at $10 \mathrm{~s}$ time resolution. These data have a $1 \sigma$ precision of $\sim 20 \mathrm{ppb}$, determined mainly by electrical noise in the observed spectra. Individual $\mathrm{CO}$ profiles from all flights are provided in Figure $\mathrm{S} 1$ in the Supplement.

\subsubsection{Ozone $\left(\mathrm{O}_{3}\right)$}

$\mathrm{O}_{3}$ was measured with $8 \%$ precision at $1 \mathrm{~Hz}$ time resolution by the FOZAN-II (Fast OZone ANalyzer) instrument developed and operated by the Central Aerological Observatory, Russia, and the Institute of Atmospheric Science and Climate, Italy (Ulanovsky et al., 2001; Yushkov et al., 1999). FOZAN-II is a two-channel solid-state chemiluminescent instrument featuring a sensor based on Coumarin 307 dye on a cellulose acetate-based substrate, and is equipped with a high-accuracy ozone generator for periodic calibration of each channel every $15 \mathrm{~min}$ during the flight, ensuring an accuracy better than $10 \mathrm{ppb}$ in the observations. The measured concentration range is $10-500 \mu \mathrm{g} \mathrm{m}^{-3}$, operating temperature range is -95 to $+40^{\circ} \mathrm{C}$, and the operating pressure range is $1100-30 \mathrm{mbar}$ (about $0-22 \mathrm{~km}$ ). The instrument was calibrated at the ground before and after each flight by means of an ozone generator and reference ultraviolet (UV)absorption $\mathrm{O}_{3}$ monitor (Dasibi 1008-PC).

Ozone data are available from two of the three Kalamata flights in 2016 and from six of the eight Kathmandu flights in 2017. Individual $\mathrm{O}_{3}$ profiles from all flights are provided in Figure S2 in the Supplement.

\subsubsection{Nitrous oxide $\left(\mathrm{N}_{2} \mathrm{O}\right)$}

$\mathrm{N}_{2} \mathrm{O}$ was measured at $90 \mathrm{~s}$ time resolution with an average precision of $0.5 \%$ and average accuracy of about $0.6 \%$ by the High Altitude Gas AnalyzeR (HAGAR). The instrument, operated by the University of Wuppertal, comprises a two-channel gas chromatograph with an electron capture detector (ECD) measuring a suite of long-lived tracers $\left(\mathrm{N}_{2} \mathrm{O}\right.$, 
CFC-11, CFC-12, Halon-1211, $\mathrm{CH}_{4}, \mathrm{SF}_{6}, \mathrm{H}_{2}$ ) and a nondispersive IR absorption sensor for fast $\mathrm{CO}_{2}$ measurements (Homan et al., 2010). The instrument is calibrated every 7.5 min during flight with either of two standard gases, which are inter-calibrated in the laboratory with standards provided by NOAA GML (National Oceanic and Atmospheric Administration Global Monitoring Laboratory). $\mathrm{N}_{2} \mathrm{O}$ data are available for all flights of the campaign (note that the first flight on 30 August 2016 in Kalamata suffers from a comparatively poor $\mathrm{N}_{2} \mathrm{O}$ precision of $\sim 2 \%$ ).

$\mathrm{N}_{2} \mathrm{O}$ is fairly well mixed in the troposphere with a global mean surface mole fraction in 2017 of $329.8 \mathrm{ppb}$; its tropospheric distribution exhibits a steady growth of $0.9 \mathrm{ppb} \mathrm{a}^{-1}$, as well as seasonal variation, interhemispheric differences and other geographic variations (of the order of $1 \mathrm{ppb}$ ) due to surface sources (Dlugokencky et al., 2018; https://www.esrl. noaa.gov/gmd/hats/combined/N2O.html, last access: 25 January 2021). $\mathrm{N}_{2} \mathrm{O}$ is destroyed in the mid stratosphere mainly above $25 \mathrm{~km}$ by UV light and reaction with $\mathrm{O}\left({ }^{1} \mathrm{D}\right)$, with slow vertical transport to this sink region resulting in a long atmospheric lifetime of 123 (104-152) years (SPARC, 2013). For an air parcel in the lower stratosphere, an $\mathrm{N}_{2} \mathrm{O}$ mixing ratio below the tropospheric value thus indicates the presence of a fraction of photochemically aged air that has passed the sink region above.

\subsubsection{Geolocation and meteorological data}

Temperature was measured at $10 \mathrm{~Hz}$ resolution with an accuracy of $0.5 \mathrm{~K}$ and a precision of $0.1 \mathrm{~K}$ by the commercial Rosemount probe instrument Thermodynamic Complex (TDC). Pressure and geolocation data were obtained at $1 \mathrm{~Hz}$ resolution from Geophysica's avionic system. Potential temperature along the flight track was calculated from these data. Physical properties on larger scales were derived from ECMWF ERA-Interim data (Dee et al., 2011), including wind speed and direction, potential vorticity (PV), vertical velocities and radiative heating, and local temperature profiles to determine the heights of the lapse rate tropopause (LRT) and cold point tropopause (CPT).

The vertical resolution of ERA-Interim data in the tropopause region is about $1 \mathrm{~km}$, with relevant levels at 132.76, 113.42, 95.98, 80.40 and $66.62 \mathrm{hPa}$ (corresponding to about $14.23,15.33,16.50,17.74$ and $19.05 \mathrm{~km})$. Related to this vertical resolution is an uncertainty in the determination of the tropopause level. The spatio-temporal variability of the tropopause over the campaign region and period will be assessed from its standard deviation in the following.

\subsection{Dynamical coordinates}

\subsubsection{Potential temperature relative to the tropopause}

Key question Q3 (Sect. 1) addresses how the ASM vertical transport relates to the tropopause. Based on the temperature profile (note that the tropopause is sometimes also defined in terms of other parameters such as PV or chemical tracers), the tropopause in the ASM region can be defined either as the CPT, i.e. the altitude of the coldest temperature, or as the LRT, i.e. "the lowest level at which the lapse rate decreases to $2 \mathrm{~K} / \mathrm{km}$ or less, provided also that the average lapse rate between this level and all higher levels within $2 \mathrm{~km}$ does not exceed $2 \mathrm{~K} / \mathrm{km}$ " (WMO, 1957). LRT and CPT were linearly interpolated to each point along a given flight track from the surrounding reanalysis grid points. Under tropical conditions, in the majority of the cases the LRT and CPT are found at the same level; i.e. the LRT is also CPT. When they are not co-located, by definition the CPT is always higher than the LRT, and their separation typically increases with latitude (Munchak and Pan, 2014; see also Fig. S3 in the Supplement, which shows the LRT-CPT separation along the StratoClim flight tracks as a function of latitude).

Because both the LRT and the CPT can vary substantially in altitude, potential temperature and PV, we determine the respective difference in potential temperature units for our observations and introduce this difference as a new vertical coordinate (e.g. Hoor et al., 2004; Ploeger et al., 2017). Pan et al. (2018) have shown that the LRT better identifies the transition from the troposphere to the stratosphere in the tropics, and relative coordinates with respect to the LRT are used in the main figures and discussions below. Corresponding figures with respect to the CPT are provided in the Supplement to facilitate comparison with studies having a stronger focus on the CPT. For example, Brunamonti et al. (2018) used the CPT to mark the top of an "Asian tropopause transition layer (ATTL)".

\subsubsection{Monsoon equivalent latitude}

Different meteorological variables have been proposed in the literature to identify the core of the ASM circulation, including geopotential height (e.g. Bergman et al., 2013; Randel and Park, 2006), Montgomery stream function (e.g. Santee et al., 2017) and potential vorticity (PV; e.g. Garny and Randel, 2013; Ploeger et al., 2015). All of these approaches give meaningful (and similar) results when applied to monthlymean fields. Here, we follow the approach of Ploeger et al. (2015) based on the maximum PV gradient on an isentropic surface with respect to a monsoon-centred equivalent latitude (see below). As PV is an approximately conserved quantity, it correlates better with tracer distributions that involve small-scale structures, which is an advantageous quality when applied to high-resolution in situ measurements.

Monsoon equivalent latitude (MeqLat) was introduced by Ploeger et al. (2015; please refer to this reference for a comprehensive description of the MeqLat concept and its derivation) as a means of describing the position of an air mass relative to the centre of the ASM anticyclone. On the $380 \mathrm{~K}$ potential temperature surface, the location of the absolute PV minimum is defined as the ASM centre corresponding to $90^{\circ}$ 
MeqLat. As one moves away from this "ASM pole", MeqLat decreases as PV increases. The area enclosed by a given PV contour determines the corresponding MeqLat value, analogous to the decrease in latitude when moving away from the Earth's north or south pole in the definition of equivalent latitude as proposed by Nash et al. (1996). The anticyclone border (i.e. the transport barrier separating air masses inside and outside) is characterized by a maximum of the PV gradient with respect to MeqLat and typically lies around $65^{\circ}$ MeqLat, so MeqLat $>65^{\circ}$ can be considered an indicator of air inside the ASM anticyclone (Ploeger et al., 2015). This boundary identification based on the PV gradient only works well in a shallow layer around $380 \mathrm{~K}$. Therefore, we use the $380 \mathrm{~K}$ MeqLat value at the horizontal location of each measurement to determine whether it was made inside or outside the ASM anticyclone. By definition, this criterion is exact only for observations at $380 \mathrm{~K}$ and becomes increasingly uncertain with vertical distance above or below this level because the anticyclone varies in size at different levels, and it often tilts northward with altitude. However, it is the best we can do based on PV. This uncertainty in the correct identification of ASM anticyclone air masses has probably little effect on our analyses of observations around the tropopause level (i.e. around $380 \mathrm{~K}$ ), but the impact could be more significant at higher levels where more observations unrelated to the ASM may potentially be included in our analyses. Figure S4 in the Supplement shows maps of ASM anticyclone frequency for 2016 and 2017 analogous to that shown for 2011 by Ploeger et al. (2015).

\subsection{Whole Atmosphere Community Climate Model (WACCM)}

The Whole Atmosphere Community Climate Model, version 6 (WACCM6; Gettelman et al., 2019) is used in this study to provide large-scale dynamical and chemical background for the StratoClim campaign period. WACCM6 is the atmospheric component of the Community Earth System Model Version 2 (CESM2; Danabasoglu et al., 2020; Emmons et al., 2020). The WACCM6 domain extends from the Earth's surface to the lower thermosphere. For the simulation used in this study, the model uses a $0.9^{\circ} \times 1.2^{\circ}$ longitudelatitude grid, with 110 vertical levels on a hybrid-pressure vertical grid with a top at about $150 \mathrm{~km}$ (Garcia and Richter, 2019 ). For pressures $<100 \mathrm{hPa}$, the vertical coordinate is isobaric; at higher pressures the coordinate is a hybrid, transitioning to a pure terrain-following system at the surface. The vertical resolution in the UTLS is $\sim 0.5 \mathrm{~km}$. WACCM6 uses comprehensive troposphere, stratosphere, mesosphere and lower thermosphere chemistry (TSMLT; Gettelman et al., 2019). Anthropogenic emissions are from the global CAMS (Copernicus Atmosphere Monitoring Service) emission data set version 4, downloaded from the ECCARD data page: http://www.igacproject.org/sites/default/files/2018-03/ Issue_61_FebMar_2018.pdf (last access: 21 January 2021).
Fire emissions are based on the FINN inventory Version 1.5 (Wiedinmyer et al., 2011).

The WACCM6 simulation used in this study has been performed with observed sea-surface temperature and sea-ice conditions. Atmospheric winds and temperatures are nudged towards NASA GMAO GEOS5.12 meteorological analysis with a Newtonian relaxation of $50 \mathrm{~h}$ below $50 \mathrm{~km}$ using a smooth transition to no nudging at higher model levels from 50 to $60 \mathrm{~km}$. The main effect of nudging is to provide meteorological conditions that are consistent with analysed winds and temperature, allowing comparisons between WACCM6 and observed chemical distributions.

As the first application of this 110-level configuration in observational studies, we find that the representation of the UTLS dynamical structure of the ASM anticyclone and the region of active convective uplifting are both qualitatively consistent with the result of the previous 88-level configuration, which was extensively analysed in Pan et al. (2016). The representation of enhanced $\mathrm{CO}$ in the anticyclone is also found to be qualitatively consistent with the MLS (Microwave Limb Sounder) satellite data. There is a clear improvement in this run compared to the previous 88-level configuration in a much better representation of the vertical chemical gradient in the UTLS (see Fig. 5 in Sect. 3.3). The overall performance of this run in representing various processes is still under evaluation, especially the possible weaker convective uplifting introduced by the change in nudging.

\section{Observations}

\subsection{General overview}

Figure 2 gives a full three-dimensional view of the AMICA CO observations made during both StratoClim campaigns. The data have been averaged into $1^{\circ} \times 1^{\circ} \times 1 \mathrm{~km}$ longitudelatitude-altitude grid cells, and then meridional and zonal averages have been projected onto longitude-altitude and latitude-altitude space. In the Kalamata region, $\mathrm{CO}$ mixing ratios in the free troposphere were typically between 50 and $80 \mathrm{ppb}$ and only reached $100 \mathrm{ppb}$ in the lowermost $3 \mathrm{~km}$, with the latter likely due to upward mixing of local boundary layer air. By contrast, measurements in the free troposphere over $\mathrm{Nepal}$ and surrounding regions indicate elevated levels of CO around $100 \mathrm{ppb}$ at altitudes up to about $16 \mathrm{~km}$, in some cases $17 \mathrm{~km}$, i.e. throughout most of the free troposphere. These relatively large $\mathrm{CO}$ mixing ratios indicate fast and efficient transport - most likely by convection - from the boundary layer up to this level (see discussion below). Note that the convective activity was weak to moderate during the first half of the 2017 Kathmandu campaign phase and strongly increased in the second half, coinciding with a cooling of the ASM anticyclone and a corresponding rise of $\theta$ isentropes in terms of altitude (Bucci et al., 2020; Stroh et al., 2021, and 
references therein). For a large-scale perspective of the ASM region during the Kathmandu 2017 campaign, animations of WACCM-simulated CO distributions are provided as a video supplement (https://doi.org/10.5446/48163).

ERA-Interim reanalysis data show that, at the time of the 2016 campaign, Kalamata was located almost exactly at the border between the tropics and extra-tropics, defined here as the latitude where the LRT drops sharply from $16-18 \mathrm{~km}$ in the tropics to $10-13 \mathrm{~km}$ at higher latitudes (this also shows itself by the sharp PV gradient on the $380 \mathrm{~K}$ isentrope in the campaign area displayed in the top panel of Fig. 1 and in the strong increase in potential temperature difference between LRT and cold point displayed in Fig. S3). As a consequence, air masses in the tropical UTLS and in the extratropical stratosphere were probed in the same altitude range $(15-20 \mathrm{~km})$, often during the same flight. Air masses sampled in the extratropical stratosphere show a clear signature of aged stratospheric air, with small $\mathrm{CO}$ mixing ratios in the 10 to $25 \mathrm{ppb}$ range. Such air masses were not sampled in the Kathmandu area, where the LRT was always located above $16 \mathrm{~km}$ altitude and $369 \mathrm{~K}$ potential temperature.

\subsection{Trace gas distributions}

In Fig. 3, campaign-averaged $\mathrm{CO}, \mathrm{O}_{3}$ and $\mathrm{N}_{2} \mathrm{O}$ mixing ratios are shown against different horizontal and vertical coordinates. In the top row, where data are shown in latitudepotential-temperature space, average LRT and CPT levels are also shown for different latitudes. Both levels are highly variable, especially in the (higher latitude) Kalamata region. To account for this variability when separating mixing ratio data into tropospheric and stratospheric regimes, the middle row of Fig. 3 adopts $\theta$ units relative to the LRT as the new vertical coordinate (defined in Sect. 2.3.1). A similar figure using the difference in $\theta$ relative to the CPT is provided in the Supplement (Fig. S6). The clear separation between the Kalamata and Kathmandu flights in latitude space becomes less pronounced in the bottom row, where the latitude coordinate is replaced by MeqLat (see Sect. 2.3.2) to better represent measurement locations relative to the ASM (with MeqLat $=90^{\circ}$ being, by definition, at the centre of the ASM anticyclone). Nevertheless, observations obtained during the Kathmandu flights represent most of the data at larger MeqLat values.

Based on Ploeger et al. (2015), we use $65^{\circ}$ MeqLat as the boundary between inside the ASM anticyclone and outside the ASM anticyclone. This must be regarded as an approximation, because this boundary is not always sharp and readily located and can also vary over time (Ploeger et al., 2015). Moreover, defining the boundary on the $380 \mathrm{~K}$ isentropic surface introduces ambiguities for measurements collected at significantly higher or lower levels (see Sect. 2.3.2). An illustration of this problem is the cluster of samples with 4070 ppb CO just below $350 \mathrm{~K}$ in Fig. 4 that were observed in the free troposphere over the Mediterranean during the Kalamata campaign (cf. Fig. S1).
To further investigate the vertical structure inside the ASM anticyclone, layer-normalized frequency distributions of the three trace gases for all observations collected inside the anticyclone (i.e. with MeqLat $>65^{\circ}$ ) are shown in Fig. 4 for the vertical coordinates $\theta$ (top panels) and $\Delta \theta$ relative to the LRT (bottom panels; a version with potential temperature relative to the CPT is provided in the Supplement Fig. S7). Tropospheric CO mixing ratios of around $100 \mathrm{ppb}$, a clear signature of polluted air, stretch upward from the polluted boundary layer through the lower troposphere up to about $370 \mathrm{~K}$ potential temperature, corresponding to about $10-20 \mathrm{~K}$ below the LRT. The mean LRT during the campaign period is located at about $380 \mathrm{~K}$, with maximum values up to $396 \mathrm{~K}$ and minimum values down to $369 \mathrm{~K}$ (see Fig. 4). The mean CPT level is located about $10 \mathrm{~K}$ higher. Note that potential temperature is highly perturbed in this active convective region and that there is a particularly sharp vertical gradient in $\theta$ around the LRT, with a $10 \mathrm{~K}$ difference in $\theta$ corresponding to only a few hundred metres in altitude. Above the LRT, CO mixing ratios $>100 \mathrm{ppb}$ were not observed in these measurements. Above the 360-370 K level, CO gradually decreases with altitude until reaching stratospheric equilibrium values of $25 \mathrm{ppb}$ or lower between 420 and $435 \mathrm{~K}$. The observed CO decrease with increasing $\theta$ is consistent with the expected local photochemical removal during slow ascent: almost all observations fall into the purple shaded region in the top left panel of Fig. 4, which marks realistic combinations of ascent rate and $\mathrm{CO}$ lifetime. Isentropic ascent rates between 1.0 and $1.5 \mathrm{~K} \mathrm{~d}^{-1}$ are consistent with ERA-Interim-based analyses in recent studies (e.g. Garny and Randel, 2016; Legras and Bucci, 2020; Vogel et al., 2019). The reduction of the lower limit to $0.7 \mathrm{Kd}^{-1}$ is based on the assumption that ERAInterim ascent rates in the monsoon region could be similarly biased high as has been suggested for the tropical tropopause layer (TTL; e.g. Ploeger et al., 2012; Schoeberl et al., 2012). The range of $30-90 \mathrm{~d}$ for the $\mathrm{CO}$ photochemical lifetime is conservatively chosen to encompass a wide range of mainly tropospheric lifetime estimates (e.g. Holloway et al., 2000; Xiao et al., 2007; Duncan et al., 2007) and account for the fact that $\mathrm{OH}$ concentration decreases with altitude. Note that the WACCM simulation (Sect. 2.4) predicts CO lifetimes of $\sim 1$ month at $150 \mathrm{hPa}$ and $1-2$ months at $100 \mathrm{hPa}$.

Ozone, as a stratospheric tracer, behaves opposite to CO. Below about $365 \mathrm{~K}, \mathrm{O}_{3}$ mixing ratios mostly fall into the 30 $50 \mathrm{ppb}$ range and never exceed $100 \mathrm{ppb}$, consistent with expectations for tropospheric air. A significant increase in $\mathrm{O}_{3}$ with increasing altitude was observed above this level. As with the decrease in $\mathrm{CO}$, this increase in $\mathrm{O}_{3}$ is largely consistent with local photochemical production during slow ascent. The purple shaded region in the top middle panel of Fig. 4 is based on the same vertical ascent rates described for $\mathrm{CO}$ above $\mathrm{O}_{3}$ production rates of about $4 \mathrm{ppb} \mathrm{d}^{-1}$ based on Fig. 8 in Gottschaldt et al. (2017). Above about $420 \mathrm{~K}$, observed $\mathrm{O}_{3}$ is higher, probably due to significant in-mixing of 


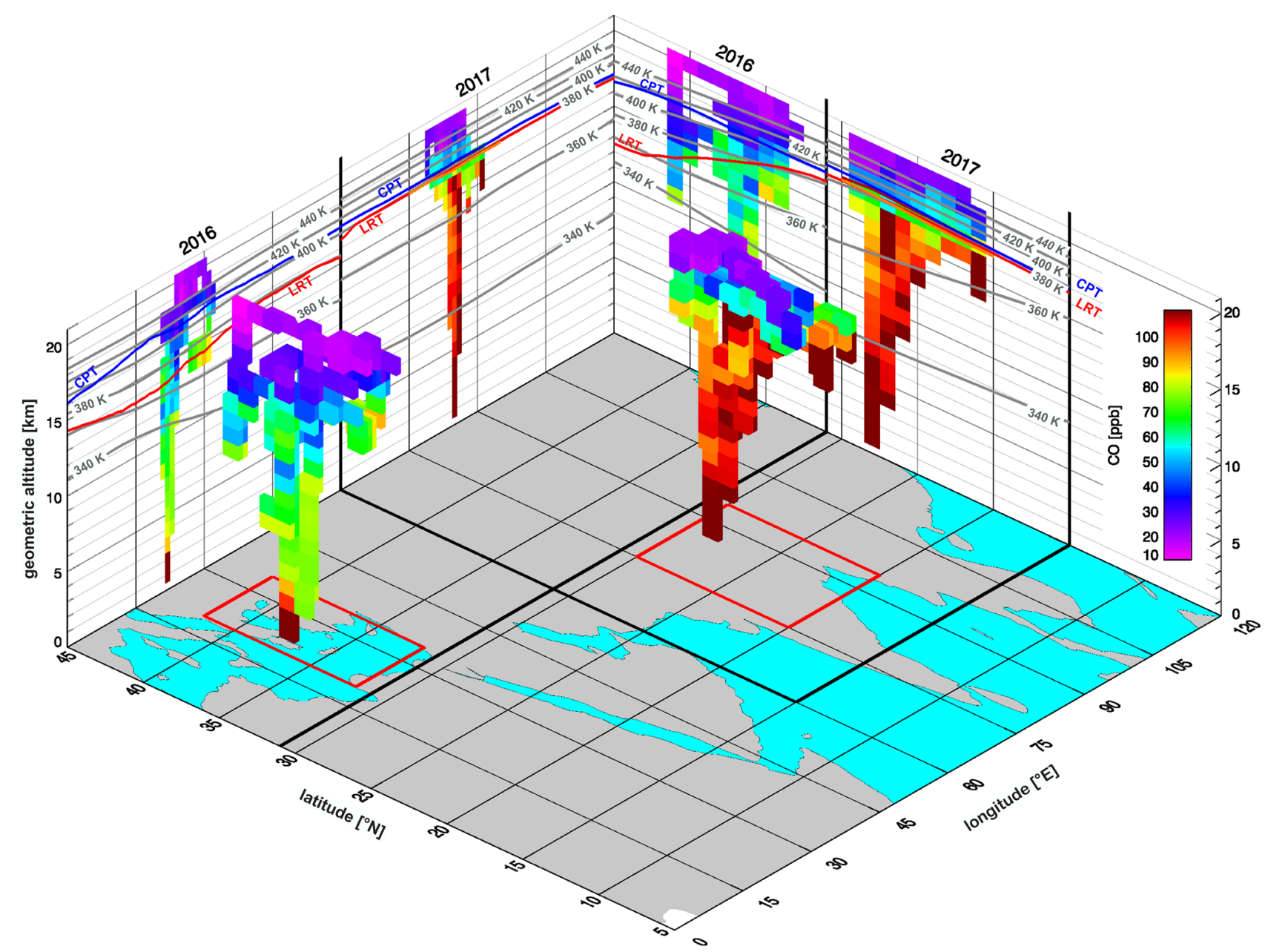

Figure 2. A 3D map of averaged CO mixing ratios observed during all StratoClim flights (raw CO profiles for all individual flights are shown in the Supplement Fig. S1). Values in 3D space represent averages in $1^{\circ} \times 1^{\circ} \times 1 \mathrm{~km}$ longitude-latitude-altitude bins. Longitude-altitude averages over all latitudes and latitude-altitude averages over all longitudes are projected onto the $x-z$ and $y-z$ planes, respectively. Grey contour lines in the $x-z$ and $y-z$ planes show potential temperature levels averaged meridionally and zonally over the areas marked on the map by the thick black lines; red and blue lines show LRT and CPT heights averaged over the same areas (based on ERA-Interim reanalysis products during the respective campaign phases).

stratospheric air above this level, consistent with significant reductions in $\mathrm{N}_{2} \mathrm{O}$ mixing ratios (see below).

A noteworthy feature in Fig. 4 is that the gradual decrease in $\mathrm{CO}$ and the gradual increase in $\mathrm{O}_{3}$ show no obvious discontinuities, on average, at the LRT or CPT. However, during the StratoClim campaign the LRT marked the vertical limit above which even individual occurrences of $\mathrm{CO}>100 \mathrm{ppb}$ were not observed (Fig. 4, bottom left panel).

$\mathrm{N}_{2} \mathrm{O}$ measurements are used to assess the role of in-mixing of stratospheric air at different levels. The local tropospheric $\mathrm{N}_{2} \mathrm{O}$ mixing ratio is determined by averaging all observations below $360 \mathrm{~K}$ potential temperature, which yields a value of $332.7 \pm 1.7 \mathrm{ppb}$. We then examine the decrease in $\mathrm{N}_{2} \mathrm{O}$ with increasing altitude above this level (Figs. 3 and 4). Significant reductions in $\mathrm{N}_{2} \mathrm{O}$ mixing ratios (unambiguously indicating significant stratospheric in-mixing) were observed only above about $395 \mathrm{~K}$ potential temperature and for $\Delta \theta$ more than $15 \mathrm{~K}$ above the mean LRT. Between 400 and $410 \mathrm{~K}$, these reductions become more substantial and a clear decline with increasing potential temperature is visible above this level. From the $\mathrm{N}_{2} \mathrm{O}$ measurements, we can estimate the fraction of aged extratropical air entrained into the anticyclone at $400 \mathrm{~K}$, following the approach of Homan et al. (2010; there estimating the extratropical fraction of TTL air). Defining "aged" here as residing in the stratosphere longer than the lifetime of $\mathrm{CO}$, we select as aged parcels those with $\mathrm{CO}<37 \mathrm{ppb}(\sim 1 / e$ times the tropospheric $\mathrm{CO}$ value of $100 \mathrm{ppb}$ ) from the 2016 Kalamata campaign outside the anticyclone, which exhibit a mean $\mathrm{N}_{2} \mathrm{O}$ mixing ratio of $320 \pm 3.7 \mathrm{ppb}$ (1 standard deviation) in the potential temperature range 390 to $400 \mathrm{~K}$. Considering the upper end of the $\mathrm{N}_{2} \mathrm{O}$ range and allowing for a $1 \mathrm{ppb}$ increase between 2016 


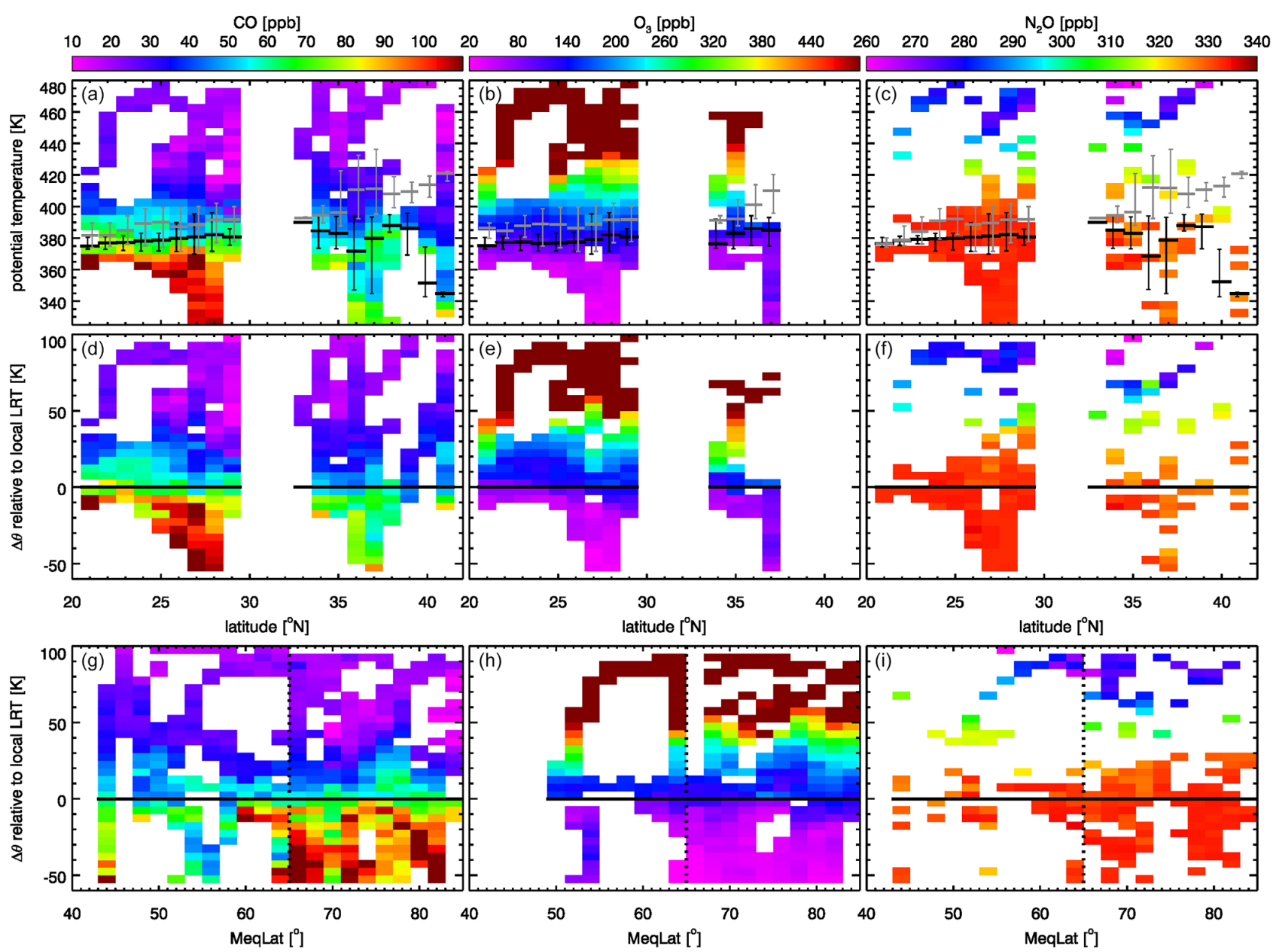

Figure 3. Panels (a-c) show $\mathrm{CO}(\mathbf{a}), \mathrm{O}_{3}(\mathbf{b})$ and $\mathrm{N}_{2} \mathrm{O}$ (c) mixing ratios averaged from both deployments into $1^{\circ}$ latitude $\times 5 \mathrm{~K}$ potential temperature bins. Black and grey bars show average and minimum/maximum LRT and CPT heights, respectively, for all measurements made in each $1^{\circ}$ latitude bin. Note that the bins with valid data for $\mathrm{CO}, \mathrm{O}_{3}$ and $\mathrm{N}_{2} \mathrm{O}$ do not exactly match due to different data coverage for the AMICA, FOZAN and HAGAR instruments. Panels (d-f) show the same data with potential temperature relative to the LRT (see Sect. 2.3.1) as the vertical coordinate. In panels (g-i), the horizontal coordinate is transformed to MeqLat with the vertical dotted line marking the $65^{\circ}$ ASM anticyclone boundary (see Sect. 2.3.2). The number of samples and standard deviation in each bin are given in Fig. S5 in the Supplement.

and 2017 , we estimate $\mathrm{N}_{2} \mathrm{O}_{\text {aged }}<324.7 \mathrm{ppb}$, i.e. at least $8 \mathrm{ppb}$ below the mean tropospheric value in the Kathmandu region ( $332.7 \mathrm{ppb})$. Inside the anticyclone at $400 \mathrm{~K}$ potential temperature, the average $\mathrm{N}_{2} \mathrm{O}$ decreased by only $2.4 \mathrm{ppb}$ from this tropospheric value, consistent with an average fraction of in-mixed aged air of at most $30 \%$ (i.e. $2.4 \mathrm{ppb} / 8 \mathrm{ppb}$ ).

\section{3 $\mathrm{CO}-\mathrm{O}_{3}$ tracer correlations}

Mixing is an important physical process impacting the transport of chemical constituents and a key mechanism for irreversible stratosphere-troposphere exchange (Gettelman et al., 2011). Signatures of mixing in the tropopause region are frequently observed as "mixing lines" in (non-linear) correlations between tropospheric (like $\mathrm{CO}$ ) and stratospheric (like $\mathrm{O}_{3}$ ) tracers (e.g. Marcy et al., 2004; Hoor et al., 2002; Fis- cher et al., 2000; Hintsa et al., 1998). Thus, mixing layers separating the troposphere from the overlying stratosphere are marked by relatively high concentrations of both $\mathrm{CO}$ and $\mathrm{O}_{3}$. This mixing itself manifests in the $\mathrm{CO}-\mathrm{O}_{3}$ phase space as deviations from the pure tropospheric and pure stratospheric branches, which in the absence of mixing tend to form an L-shaped distribution (Pan et al., 2010, 2007). Such idealized L-shaped $\mathrm{CO}-\mathrm{O}_{3}$ correlations have been used many times to illustrate near-perfect segregation of the troposphere and stratosphere without any mixing layer in between (e.g. Konopka and Pan, 2012).

Figure 5 shows $\mathrm{CO}-\mathrm{O}_{3}$ correlation plots of all coincident $\mathrm{CO}$ and $\mathrm{O}_{3}$ observations from the Kathmandu 2017 flights (left) and from WACCM (right; $\mathrm{CO}-\mathrm{O}_{3}$ mixing ratios in the WACCM distributions are the model outputs from the grid 


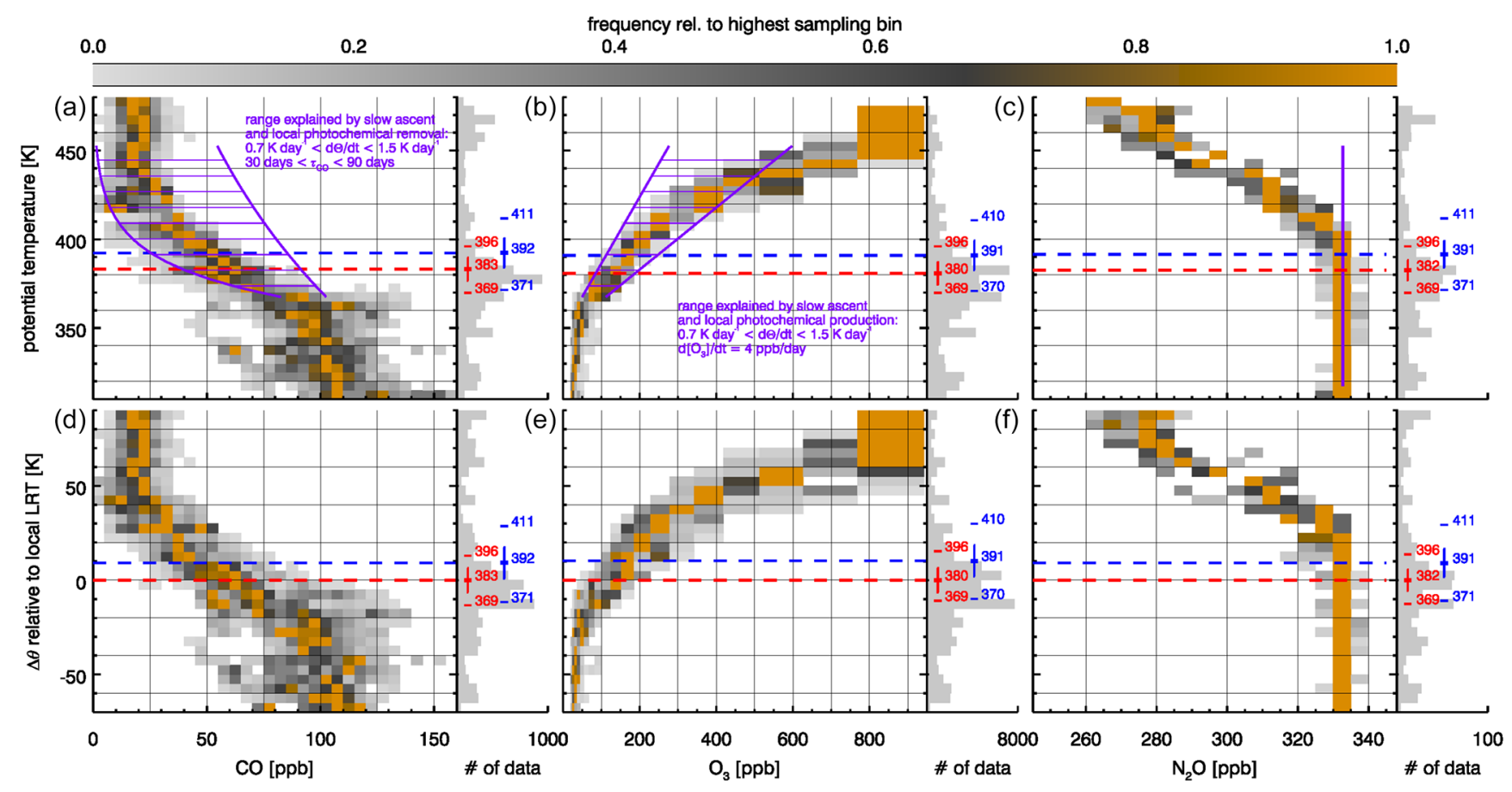

Figure 4. Layer-normalized relative frequency distributions of $\mathrm{CO}(\mathbf{a}, \mathbf{d}), \mathrm{O}_{3}(\mathbf{b}, \mathbf{e})$ and $\mathrm{N}_{2} \mathrm{O}(\mathbf{c}, \mathbf{f})$ inside the $\mathrm{ASM}$ anticyclone $\left(\mathrm{MeqLat}>65^{\circ}\right)$ for vertical coordinates of potential temperature $(\mathbf{a}-\mathbf{c})$ and potential temperature difference relative to the local LRT $(\mathbf{d}-\mathbf{f})$. The number of observations on each vertical level is plotted as the grey histogram along the right side of each panel (scaling from 0 to the number at the right end of the axis). The mean (with standard deviation), minimum and maximum LRT and CPT levels are also shown in red and blue, respectively (values vary slightly between the columns, because as explained in the Fig. 3 caption, the bins with valid measurements are different for each instrument). Areas marked in purple in the $\mathrm{CO}$ and $\mathrm{O}_{3}$ panels indicate the range of concentrations consistent with photochemical removal or production during slow ascent (see text for the rationale behind the chosen ranges). In the $\mathrm{N}_{2} \mathrm{O}$ panel, the purple line denotes the average HAGAR $\mathrm{N}_{2} \mathrm{O}$ in the troposphere (below $360 \mathrm{~K}$ potential temperature) during the 2017 campaign.

locations closest to the observations in both time and space). Observed $\mathrm{CO}-\mathrm{O}_{3}$ correlations do not show an ideal $\mathrm{L}$ shape nor distinct mixing lines between the tropospheric and stratospheric branches. Rather, there is a smooth curved transition from the tropospheric $\mathrm{CO}$ branch to the stratospheric $\mathrm{O}_{3}$ branch with increasing $\theta$, consistent with a transition layer in which the ascending air undergoes photochemical processing. This interpretation is supported by quasi-coincident $\mathrm{N}_{2} \mathrm{O}$ observations largely showing near-tropospheric values in the transition zone between the high-CO tropospheric branch and the high- $\mathrm{O}_{3}$ stratospheric branch (Fig. 5 inset). The points circled in red in Fig. 5 (observed during both ascent and descent near Kathmandu during a flight on 31 July) are speculatively associated with fresh convective outflow, for which $\mathrm{O}_{3}$ mixing ratios are somewhat elevated due to lightning $\mathrm{NO}_{x}$.

The spatial distribution of the $\mathrm{CO}-\mathrm{O}_{3}$ pairs in the transition layer (dashed magenta rectangle in Fig. 5) is shown in Fig. 6 by using altitude, pressure and potential temperature as the vertical coordinate (from left to right, respectively). From these distributions, we deduce a vertical extent of the transition layer (Fig. 6) with respect to these coordinates of $\sim 16-19 \mathrm{~km}, \sim 70-115 \mathrm{hPa}$ and $\sim 365-415 \mathrm{~K}$. Figure 5 also shows that the lower tropospheric end of the transition layer is clearly located below the LRT, and the higher stratospheric end is located above the LRT. A more detailed analysis of LRT and CPT locations within the transition layer is given in Fig. 7. Observed $\mathrm{CO}-\mathrm{O}_{3}$ pairs with transition layer characteristics are found mainly between $15 \mathrm{~K}$ below and $35 \mathrm{~K}$ above the local LRT (a few very rare outliers are even found up to $45 \mathrm{~K}$ above the LRT), with roughly one-third of the pairs found below and two-thirds above the LRT. Transition layer $\mathrm{CO}-\mathrm{O}_{3}$ pairs are observed mainly between $30 \mathrm{~K}$ below and $30 \mathrm{~K}$ above the CPT, with roughly two-thirds below and one-third above the CPT.

Compact $\mathrm{CO}-\mathrm{O}_{3}$ correlations were also observed during the START08 (Stratosphere-Troposphere Analyses of Regional Transport, 2008; https://www.acom.ucar.edu/start/, last access: 21 January 2021) campaign, during which air masses originating from the TTL were sampled in the extratropical UTLS region (Vogel et al., 2011, their Fig. 3). Similar to our observations within the anticyclone, photochemical processing within the observed air masses outweighed mixing effects. They attributed this result to the long transit times associated with air mass transport from tropical convective outflow to the upper part of the TTL, well above the 

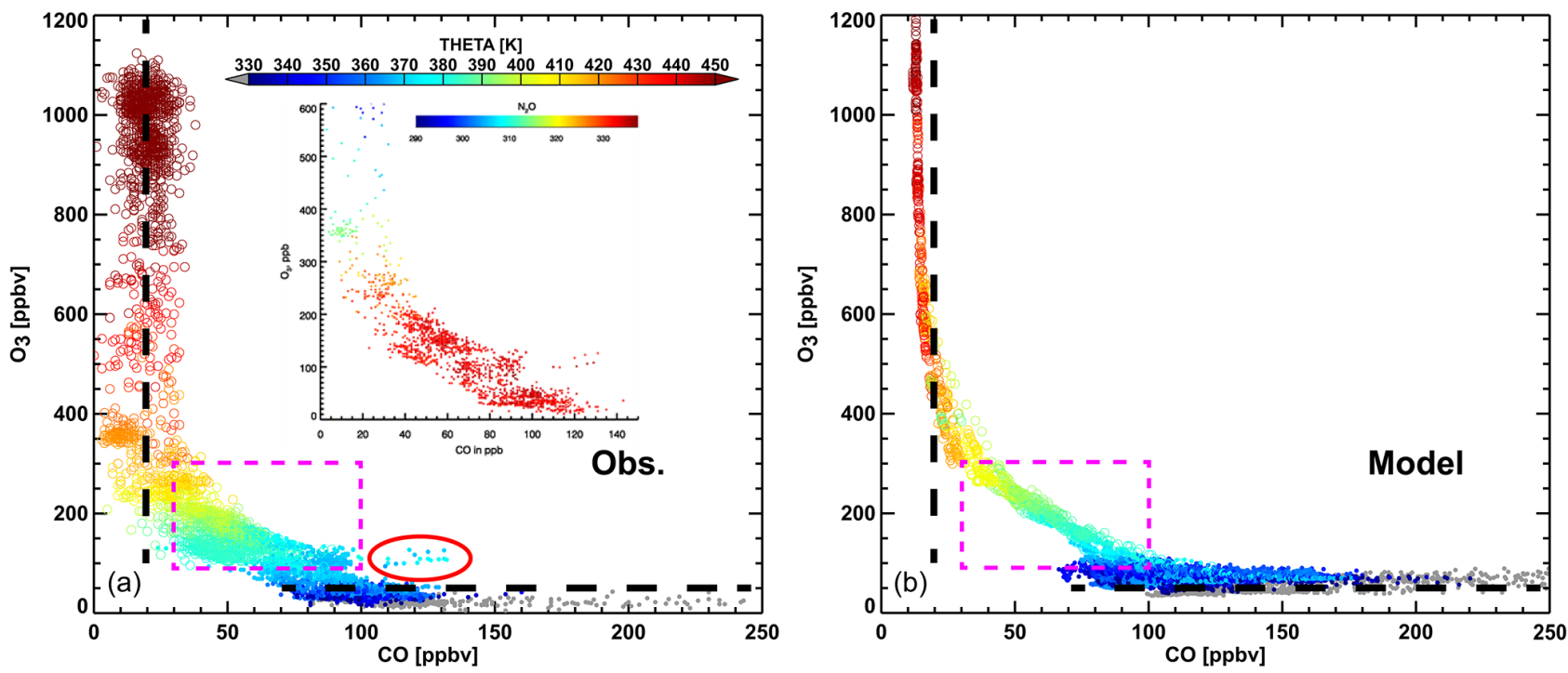

Figure 5. $\mathrm{O}_{3}$ vs. $\mathrm{CO}$ relationships in tracer-tracer space based on observations (a) and WACCM simulations (b) for the $2017 \mathrm{Kathmandu}$ flights. The data points are coloured according to their potential temperature level (with grey indicating $\theta<330 \mathrm{~K}$ ), and they are shown by two types of symbols for above (circle) and below (dots) the LRT. WACCM grid points are selected to match the flight dates and are sampled in grid points nearest to the flight track (within $\pm 1^{\circ}$ in latitude and longitude) to minimize spatio-temporal offsets. Dashed lines indicate three "regimes" identified by the $\mathrm{O}_{3}-\mathrm{CO}$ relationship, corresponding to the troposphere (horizontal dashed line), the stratosphere (vertical dashed line) and the transition layer (magenta rectangle). We chose criteria of $30 \mathrm{ppb}<\mathrm{CO}<100 \mathrm{ppb}$ and $80 \mathrm{ppb}<\mathrm{O}_{3}<300 \mathrm{ppb}$ to assign measurements to the transition layer (i.e. both gases having neither tropospheric nor stratospheric values). The points marked by the red oval are likely produced by convective transport and $\mathrm{O}_{3}$ production from lightning $\mathrm{NO}_{x}$ (see text). The inset in (a) shows the observed $\mathrm{O}_{3}$ vs. $\mathrm{CO}$ relationship coloured according to quasi-simultaneous $\mathrm{N}_{2} \mathrm{O}$ observations (points are only displayed if the time of measurement is within $30 \mathrm{~s}$ of a HAGAR $\mathrm{N}_{2} \mathrm{O}$ measurement and if the difference in $\theta$ at the times of $\mathrm{CO} / \mathrm{O}_{3}$ and $\mathrm{N}_{2} \mathrm{O}$ measurements is less than $2.5 \mathrm{~K}$ ).
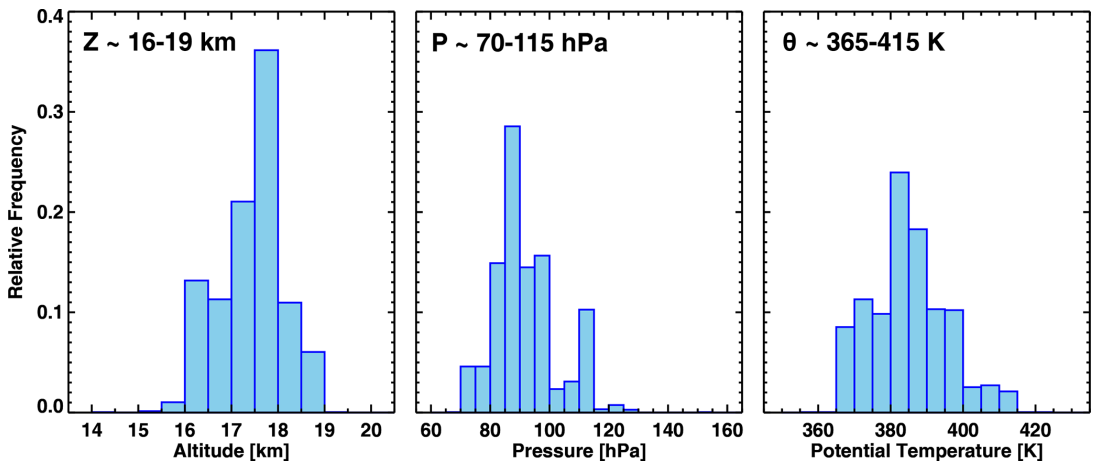

Figure 6. Relative frequency distributions of transition layer measurements in altitude, pressure and $\theta$ coordinates.

level of zero radiative heating (LZRH), which allows time for gradual changes in the $\mathrm{CO}-\mathrm{O}_{3}$ correlation. The relatively fast isentropic transport from the upper part of the TTL to the extra-tropics where the START08 flights took place is less crucial.

Overall, WACCM represents the measured correlations well. The curved part of the correlation representing the transition layer is clearly visible, and the simulation closely matches observations with respect to $\mathrm{CO}-\mathrm{O}_{3}$ coordinates as well as corresponding potential temperature levels. The overall correlation is somewhat more compact in the model compared to the observations. The spread of stratospheric
CO measurements from AMICA is about 20 ppbv, which is consistent with the reported measurement precision (see Sect. 2.2.1); by contrast, WACCM CO shows hardly any spread. In addition to the effect of the relatively coarse model grid size, this compactness might reflect the fact that the model does not represent all sources of natural variability (e.g. it does not calculate explicitly the local effects of smallscale gravity waves). 


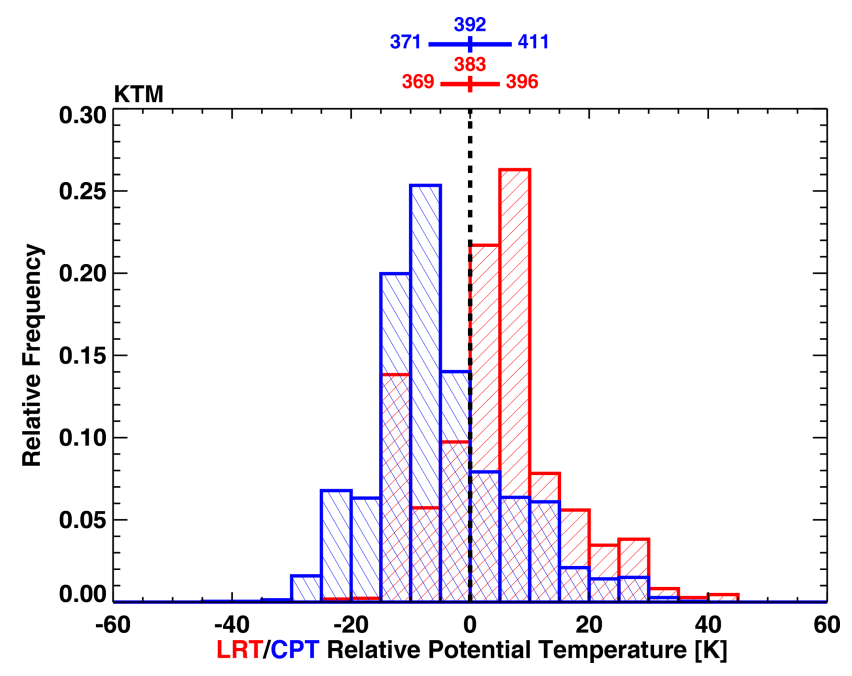

Figure 7. Transition layer in tropopause-relative potential temperature coordinates. Histograms show normalized relative frequency distributions of transition layer measurements as defined in the text. The distribution relative to the LRT (CPT) is shown in red (blue). The mean and the range of the LRT and CPT in potential temperature coordinates (as shown in Fig. 4) are given in matching colours above the zero line.

\section{Discussion}

We now address questions Q1-Q4 formulated in Sect. 1 based on the results presented in Sect. 3. In each subsection below, we discuss one question individually. A refined overall picture of vertical transport in the ASM anticyclone region near the tropopause is then given in Sect. 5.

\subsection{Rapid convective transport}

Our results provide clear evidence of chimney-like vertical transport from the boundary layer to the tropopause over Nepal and northern India, where almost the entire troposphere shows CO mixing ratios similar to those in the polluted boundary layer. Such high CO mixing ratios are consistently observed up to $360 \mathrm{~K}$, often up to $370 \mathrm{~K}$ and occasionally up to $380 \mathrm{~K}$. The absence of observed CO mixing ratios close to or above $100 \mathrm{ppb}$ at levels above $380 \mathrm{~K}$ indicates that we did not observe any occurrences of convective outflow above the tropopause immediately prior to the measurement time. However, after mixing with the local background following transport to this level, signatures of deep convection in $\mathrm{CO}$ and $\mathrm{O}_{3}$ are expected to be small and may therefore not be apparent, so we cannot exclude the occurrence of rapid convective uplift reaching up to or even above the tropopause based on our observations. Nevertheless, the absence of significant $\mathrm{N}_{2} \mathrm{O}$ reductions below $400 \mathrm{~K}$ (Sect. 3.2) and the shape of the $\mathrm{CO}-\mathrm{O}_{3}$ correlations, with little indication for direct mixing between the tropospheric and stratospheric branches (Sect. 3.3), reveal that the chemi- cal composition in the $370-400 \mathrm{~K}$ region cannot be explained by very deep convection mixing with aged stratospheric air. Rather, overshoots penetrating the tropopause mix into the tropospheric air slowly rising out of the $360-370 \mathrm{~K}$ main convective outflow layer. Our observations provide clear evidence that this slow upwelling (discussed in Sect. 4.2) and not overshooting convection is the major pathway for air crossing the tropopause in the ASM anticyclone and that the fast chimney-like transport related to convection does indeed stop below the tropopause as suggested by Pan et al. (2016), at least on a synoptic scale. It should be noted that this result does not contradict the significance of overshooting convection for species such as $\mathrm{H}_{2} \mathrm{O}$ that are subject to microphysical removal at the CPT (e.g. Ueyama et al., 2018) and that evidence for overshooting convection occurring in the StratoClim year has been shown (Legras and Bucci, 2020).

Although our observations support the hypothesis of significant input into the anticyclone from a chimney region centred near the southern flank of the Tibetan Plateau, the campaign did not cover a wide enough region to characterize the relative contributions of convection from other sources based solely on the observations. Recent studies have demonstrated horizontal transport of convective outflow from locations over China into the ASM anticyclone (Lee et al., 2019; Yuan et al., 2019) as well as injections into the ASM anticyclone from tropical typhoons (Li et al., 2017, 2020). Evidence for such import into the air masses probed in 2017 has been shown in trajectory studies (Bucci et al., 2020; Lee et al., 2020).

\subsection{Transition to slow upwelling}

From our observations, we constrain the top of the main convective outflow layer to about $16 \mathrm{~km}$ altitude or $370 \mathrm{~K}$ potential temperature, although a few occurrences of convective signatures are observed up to $380 \mathrm{~K}$. Above this level, the gradual decline in $\mathrm{CO}$ and gradual increase in $\mathrm{O}_{3}$ suggest continued slow ascent on timescales comparable to those on which $\mathrm{CO}$ is photochemically destroyed and $\mathrm{O}_{3}$ is photochemically produced (Fig. 4). This dynamically driven slow upwelling is radiatively balanced and is less geographically confined than the convective uplift. Pure trajectory models show an "upward spiralling motion of air" extending over large parts of the ASM anticyclone (Vogel et al., 2019; Legras and Bucci, 2020).

This picture is consistent with mean diabatic heating rates from the ERA-Interim reanalysis in July and August (Fig. 8). Relatively strong total diabatic tendencies exceeding $1 \mathrm{~K} \mathrm{~d}^{-1}$ extend upward into the upper troposphere in the tropical part of the monsoon region, south of $\sim 30^{\circ} \mathrm{N}$ and east of $\sim 70^{\circ} \mathrm{E}$. This diabatic chimney results from frequent deep convective activity up to around $370 \mathrm{~K}$, although single convective events may reach higher. Legras and Bucci (2020) show high clouds in 2017 to be mostly distributed between 340 and $370 \mathrm{~K}$, with some rare convective events reaching up to 
$400 \mathrm{~K}$. This is very similar to the cloud top height distribution over the ASM region that was shown for 2007 by Ueyama et al. (2018).

It can be seen in the right panels in Fig. 8 that the convective activity extends clearly above the level of zero radiative heating (LZRH). Thus, radiatively balanced upwelling (Fig. 8, middle panels) leads to continued upward motion of the air masses. In ERA-Interim, positive isentropic vertical velocities up to $1.5 \mathrm{~K} \mathrm{~d}^{-1}$ (comparable with upwelling in the "shallow branch" of the Brewer-Dobson circulation in the tropics, e.g. Wright and Fueglistaler, 2013) are present well above the $380 \mathrm{~K}$ level. These rates are consistent with the range used for the purple shading in Fig. 4 and thus with the observed $\mathrm{CO}$ decline and $\mathrm{O}_{3}$ production with increasing potential temperature (Fig. 4). Note that this is not quantitatively conclusive, because the respective photochemical processing rates are only rough estimates. In addition, precise conclusions on upwelling rates may be affected by uncertainties associated with using PV at $380 \mathrm{~K}$ to identify insideanticyclone points (cf. Sect. 2.3.2). It should also be noted that other reanalysis data sets may yield quantitatively different results (e.g. Wright and Fueglistaler, 2013; Tao et al., 2019).

\subsection{Relationship between the transition region and the tropopause}

As stated in Sect. 4.1, our observations show no evidence of convection crossing the tropopause. At respective mean potential temperature levels of $380 \mathrm{~K}$ (minimum: $369 \mathrm{~K}$, maximum: $396 \mathrm{~K}$ ) and $390 \mathrm{~K}$ (min: $370 \mathrm{~K}$, max: $411 \mathrm{~K}$ ), both the LRT and the CPT are located within the radiative upwelling regime described in Sect. 4.2. CO mixing ratios in the ASM anticyclone do not drop any more sharply at the LRT or CPT than in the regions immediately above or below these levels, and they remain greater than stratospheric background concentrations up to about $40 \mathrm{~K}$ above the LRT and $30 \mathrm{~K}$ above the CPT. The absence of any sharp transition implies that neither the LRT nor the CPT represents a vertical transport barrier for these species (neglecting, for the present discussion, microphysical processes and constituents affected by them), consistent with earlier studies (e.g. Vogel et al., 2019). The fact that the LRT and CPT are located well below the level of significant stratospheric in-mixing (see Sect. 4.4) implies that these levels do not represent separation between the troposphere and the stratosphere in the ASM anticyclone in either a dynamical or chemical sense. Thus the "tropospheric bubble" (Pan et al., 2016) not only extends to an exceptionally high tropopause but also above that tropopause.

In the transition layer $(\sim 365-415 \mathrm{~K})$, the air appears to be largely isolated within the ASM anticyclone, which is visible in the $\mathrm{N}_{2} \mathrm{O}$ observations in this study (Sect. 3.2). The isolation of air has also been reported in other StratoClim studies (e.g. Brunamonti et al., 2018; Legras and Bucci, 2020) and in previous publications (e.g. Randel and Park, 2006; Park et al.,
2007). Therefore, the higher-than-stratospheric-background $\mathrm{CO}$ values in the transition layer indicate that vertical crosstropopause transport occurred within the ASM region. This type of evidence of vertical transport has also been seen from previous in situ measurements of water vapour (Bian et al., 2012) and particle profiles (Yu et al., 2017) over the Tibetan Plateau. As shown by the $\mathrm{CO}-\mathrm{O}_{3}$ correlations (Fig. 5), WACCM reproduces the smooth transition from tropospheric to stratospheric character over a potential temperature range comparable to the observations, encompassing the range of LRT and CPT.

\subsection{In-mixing of stratospheric air}

Taking $\mathrm{N}_{2} \mathrm{O}$ mixing ratios significantly below the current tropospheric value as an indicator for the contribution of stratospheric air (Sect. 3.2), mixing of the rising ASM air with older stratospheric air starts to become clearly visible at about $400 \mathrm{~K}$ potential temperature. A further indication of stratospheric in-mixing is $\mathrm{O}_{3}$ mixing ratios exceeding the range explained by local photochemical production above $420 \mathrm{~K}$ (Fig. 4). CO mixing ratios at $415 \mathrm{~K}$ and above largely match the stratospheric background value (Fig. 4 and Sect. 3.3), indicating that the tropospheric character of the ASM anticyclone ceases at or below this level. Individual observations of slightly elevated CO are found up to $435 \mathrm{~K}$ where, based on the radiative upwelling rates and $\mathrm{CO}$ lifetimes discussed in Sect. 3.2, CO photochemical decay to equilibrium values is expected to be complete. A contribution of ASM anticyclone air at potential temperature levels up to $460 \mathrm{~K}$ had been demonstrated by Vogel et al. (2019) using a longer-lived tracer than $\mathrm{CO}$. The significant isolation of the ASM anticyclone air up to $400 \mathrm{~K}$ and the rapid weakening of this isolation in the range between 400 and $435 \mathrm{~K}$ shown by our observations is roughly consistent with previous analyses of ASM confinement using trajectory analyses (Randel and Park, 2006; Brunamonti et al., 2018; Legras and Bucci, 2020).

\section{Conclusions}

In situ observations of $\mathrm{CO}, \mathrm{O}_{3}$ and $\mathrm{N}_{2} \mathrm{O}$ were collected during two aircraft campaigns near the edge and near the centre of the ASM anticyclone. $\mathrm{CO}$ and $\mathrm{N}_{2} \mathrm{O}$ are tropospheric tracers with short and long photochemical lifetimes, respectively, while $\mathrm{O}_{3}$ is a mainly stratospheric tracer. Analysis of these observations helps us to further fill in the emerging picture of vertical transport in the ASM anticyclone, confirming and extending earlier studies:

- A "fast convective chimney" lifts polluted boundary layer air to the ASM upper troposphere, with the main outflow below $370 \mathrm{~K}$. Evidence of this chimney occasionally reaches up to the local LRT around $380 \mathrm{~K}$ but was not observed above this level (Figs. 2, 3, 4 and 6). 

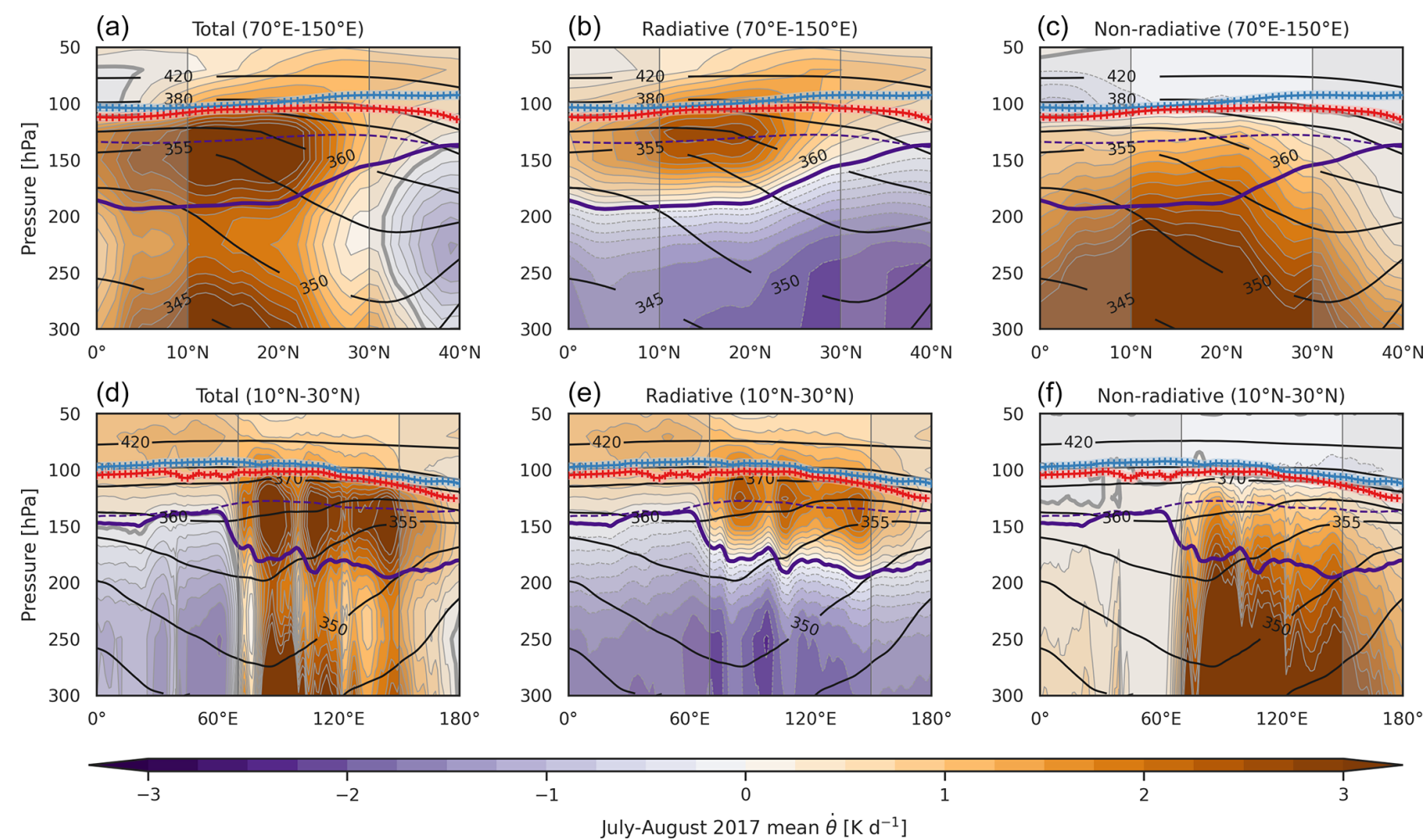

Figure 8. Zonally (a-c) and meridionally $(\mathbf{d}-\mathbf{f})$ averaged total $(\mathbf{a}, \mathbf{d})$, radiative $(\mathbf{b}, \mathbf{e})$ and non-radiative (c, f) diabatic potential temperature tendencies $(\mathrm{d} \theta / \mathrm{d} t)_{\text {diab }}$ based on the ERA-Interim reanalysis for July-August 2017 . As demarcated by the vertical grey lines and bolder colours on the respective panels, zonal averages are calculated over $70-150^{\circ} \mathrm{E}$ and meridional averages over $10-30^{\circ} \mathrm{N}$ with area weights applied. Black contours show potential temperature. Purple contours show the vertical location of the LZRH based on the zero contour in time-mean radiative heating rates under all-sky (solid) and clear-sky (dashed) conditions. LRT and CPT are shown in red and blue, respectively. Averaging ranges for $\theta$ contours, LZRH, LRT and CPT are the same as those for $(\mathrm{d} \theta / \mathrm{d} t)_{\mathrm{diab}}$.

- Inside the ASM anticyclone, above the level of main convective outflow, upward transport of air continues at slower rates roughly consistent with vertical velocities and heating rates from reanalysis data and on timescales largely consistent with photochemical removal and production of $\mathrm{CO}$ and $\mathrm{O}_{3}$, respectively (Figs. 4 and 5). Our results are consistent with the idea of air "spiralling" upward inside the ASM anticyclone, as recently described by Vogel et al. (2019).

- Air crosses the tropopause vertically during this radiatively balanced ascent, with neither the LRT nor the CPT marking sharp discontinuities for gases not affected by microphysics; the "tropospheric bubble" (Pan et al., 2016) extends above the tropopause (Figs. 4 and 7).

- Below about $400 \mathrm{~K}$, air is to a large extent horizontally isolated within the ASM anticyclone and in-mixing of stratospheric air from outside is not a dominant factor $\left(\mathrm{N}_{2} \mathrm{O}\right.$ in Fig. 4).

- There is no evidence for a sharp vertical boundary marking the top of the ASM anticyclone. The isolation starts to weaken at $400 \mathrm{~K}$, and the degree of mixing with surrounding stratospheric air smoothly increases towards higher levels (decreasing $\mathrm{N}_{2} \mathrm{O}$ in Fig. 4), consistent with what was shown by Vogel et al. (2019). Clear signatures of tropospheric air undergoing slow chemical processing are retained up to at least $415 \mathrm{~K}$ (Figs. 4 and 6).

This picture corresponds well to that proposed in a study by Ploeger et al. (2017), who postulated that vertical crosstropopause transport dominates inside the ASM anticyclone, followed by quasi-horizontal transport along isentropes above the tropopause into the tropics and into the $\mathrm{NH}$ extratropical stratosphere. It should be noted, however, that while our observations clearly show cross-tropopause transport within the ASM anticyclone, they do not necessarily contradict horizontal export of air at lower levels, which has, in fact, been shown to occur by others (e.g. Legras and Bucci, 2020; Vogel et al., 2019; Yan et al., 2019). The suggested "two-stage" vertical transport regime with fast convective uplift followed by slow radiative upwelling is consistent with recent trajectory analyses presented by Legras and Bucci (2020) and Vogel et al. (2019), who both show that this upwelling is not localized but rather follows a broad spiral 
over the entire ASM anticyclone domain. Our results are also consistent with the ATTL picture proposed by Brunamonti et al. (2018). As stated in Sect. 4.1, our picture of slow upwelling dominating vertical transport across the tropopause does not exclude the occurrence of overshooting events (the significance of which has been emphasized by Ueyama et al., 2018, and Legras and Bucci, 2020), so the interpretation by Brunamonti et al. (2018) of a shallow layer of enhanced $\mathrm{H}_{2} \mathrm{O}$ mixing ratios above the CPT as an indication of overshooting convection crossing the CPT is not in conflict with this picture. Given the $\sim 5 \mathrm{~K}$ temperature drop in the ASM anticyclone at the beginning of August described by Brunamonti et al. (2018), the enhanced $\mathrm{H}_{2} \mathrm{O}$ could also result from earlier ascent through a warmer CPT. The concept of the Lagrangian cold point rather than the local CPT being the relevant feature in limiting $\mathrm{H}_{2} \mathrm{O}$ transport has been described for the TTL by Pan et al. (2019), and it will be interesting to investigate this further with $\mathrm{H}_{2} \mathrm{O}$ observations from the two airborne campaigns.

Code availability. CESM2 WACCM6 software is available for download at https://escomp.github.io/CESM/versions/cesm2.1/ html/downloading_cesm.html (US National Science Foundation, 2020).

Data availability. All data will soon be accessible via the HALO database at https://halo-db.pa.op.dlr.de/mission/101 (German Aerospace Center, 2021). In the meantime, they can be provided by the principal investigators (MvH for AMICA; VY and FR for FOZAN; CMV for HAGAR) upon request.

Video supplement. The video supplement showing animations of WACCM-simulated CO distributions is available online at: https: //doi.org/10.5446/48163 (Honomichl et al., 2020).

Supplement. The supplement related to this article is available online at: https://doi.org/10.5194/acp-21-1267-2021-supplement.

Author contributions. MvH, FP, PK and LLP led and devised the analyses. $\mathrm{MvH}$ and $\mathrm{CK}$ provided AMICA $\mathrm{CO}$ observations. AU, $\mathrm{VY}$ and $\mathrm{FR}$ provided FOZAN $\mathrm{O}_{3}$ observations. CMV provided HAGAR $\mathrm{N}_{2} \mathrm{O}$ observations. DEK and RRG developed the new WACCM-110L version, and ST carried out the simulations for this study. SBH extracted the $\mathrm{CO}-\mathrm{O}_{3}$ correlations from WACCM and prepared all figures related to $\mathrm{CO} / \mathrm{O}_{3}$ correlations as well as the video supplement showing the WACCM simulations over the campaign period. JSW calculated heating rates from ERA-Interim and prepared Fig. 8. MvH prepared figures related to the observations and prepared the article with contributions from all co-authors.
Competing interests. The authors declare that they have no conflict of interest.

Special issue statement. This article is part of the special issue "StratoClim stratospheric and upper tropospheric processes for better climate predictions (ACP/AMT inter-journal SI)". It is not associated with a conference.

Acknowledgements. We would like to thank the Myasishchev Design Bureau team operating the M55 Geophysica aircraft for the successful deployments and their support with instrument integration and operation and provision of avionic data. We thank the local airport and ATC (air traffic control) staff in Kalamata and Kathmandu for their support. We also thank Johannes Wintel, Valentin Lauther, Thorben Beckert, Emil Gerhardt and Lydia Eppert, who supported HAGAR operations and data analysis, as well as Nicole Spelten for preparing time-synchronized merged files that were used for our analyses. Special thanks to Fred Stroh for the tremendous spadework he put in to actually make the campaigns and flights in these locations possible and to Dipak $\mathrm{Ku}-$ mar Kharki for diplomatic support in Nepal. Campaign planning and logistics as well as the scientific interpretation was largely covered by the StratoClim project funded by the European Commission's Seventh Framework Programme (FP7/2007-2013) under grant agreement no. 603557. Additional support for this work was obtained from the German Bundesministerium für Bildung und Forschung (BMBF) under the ROMIC-SPITFIRE project (BMBFFKZ: 01LG1205), from a joint research project funded by the $\mathrm{Na}-$ tional Natural Science Foundation of China (NSFC project number 41761134097) and the German Research Foundation (DFG project number 392169209). The GEOS data used in the WACCM6 run have been provided by the Global Modeling and Assimilation Office (GMAO) at NASA Goddard Space Flight Center through the online data portal in the NASA Center for Climate Simulation. Felix Ploeger was funded by the Helmholtz Association under grant no. VH-NG-1128 (Helmholtz Young Investigators Group A-SPECi). Corinna Kloss was partly funded by the Deutsche Forschungsgemeinschaft (DFG, German Research Foundation) 409585735. We thank Michelle Santee, an anonymous reviewer, Rolf Müller and Bärbel Vogel for constructive comments on the article that helped to significantly improve this paper.

Financial support. This research has been supported by the European Commission, Seventh Framework Programme (StratoClim (grant no. 603557)), the Bundesministerium für Bildung und Forschung (grant no. BMBF-FKZ: 01LG1205), the National Natural Science Foundation of China (grant no. 41761134097), the Deutsche Forschungsgemeinschaft (grant nos. 392169209, 409585735) and the Helmholtz Association (grant no. VH-NG1128).

The article processing charges for this open-access publication were covered by a Research Centre of the Helmholtz Association. 
Review statement. This paper was edited by Rob MacKenzie and reviewed by Michelle Santee and one anonymous referee.

\section{References}

Bergman, J. W., Fierli, F., Jensen, E. J., Honomichl, S., and Pan, L. L.: Boundary layer sources for the Asian anticyclone: Regional contributions to a vertical conduit, J. Geophys. Res.-Atmos., 118, 2560-2575, https://doi.org/10.1002/jgrd.50142, 2013.

Bian, J., Pan, L. L., Paulik, L., Vömel, H., Chen, H., and Lu, D.: In situ water vapor and ozone measurements in Lhasa and Kunming during the Asian summer monsoon, Geophys. Res. Lett., 39, L19808, https://doi.org/10.1029/2012GL052996, 2012.

Brunamonti, S., Jorge, T., Oelsner, P., Hanumanthu, S., Singh, B. B., Kumar, K. R., Sonbawne, S., Meier, S., Singh, D., Wienhold, F. G., Luo, B. P., Boettcher, M., Poltera, Y., Jauhiainen, H., Kayastha, R., Karmacharya, J., Dirksen, R., Naja, M., Rex, M., Fadnavis, S., and Peter, T.: Balloon-borne measurements of temperature, water vapor, ozone and aerosol backscatter on the southern slopes of the Himalayas during StratoClim 2016-2017, Atmos. Chem. Phys., 18, 15937-15957, https://doi.org/10.5194/acp-18-15937-2018, 2018.

Bucci, S., Legras, B., Sellitto, P., D’Amato, F., Viciani, S., Montori, A., Chiarugi, A., Ravegnani, F., Ulanovsky, A., Cairo, F., and Stroh, F.: Deep-convective influence on the upper tropospherelower stratosphere composition in the Asian monsoon anticyclone region: 2017 StratoClim campaign results, Atmos. Chem. Phys., 20, 12193-12210, https://doi.org/10.5194/acp-20-121932020, 2020.

Danabasoglu, G., Lamarque, J. F., Bacmeister, J., Bailey, D. A., DuVivier, A. K. Â., Edwards, J., Emmons, L. K., Fasullo, J., Garcia, R., Gettelman, A., Hannay, C., Holland, M. M., Large, W. G., Lauritzen, P. H., Lawrence, D. M., Lenaerts, J. T. M., Lindsay, K., Lipscomb, W. H., Mills, M. J., Neale, R., Oleson, K. W., Otto-Bliesner, B., Phillips, A. S., Sacks, W., Tilmes, S., van Kampenhout, L., Vertenstein, M., Bertini, A., Dennis, J., Deser, C., Fischer, C., Fox-Kemper, B., Kay, J. E., Kinnison, D., Kushner, P. J., Larson, V. E., Long, M. C., Mickelson, S., Moore, J. K., Nienhouse, E., Polvani, L., Rasch, P. J., and Strand, W. G.: The Community Earth System Model Version 2 (CESM2), J. Adv. Model. Earth Sy., 12, e2019MS001916, https://doi.org/10.1029/2019MS001916, 2020.

Dee, D. P., Uppala, S. M., Simmons, A. J., Berrisford, P., Poli, P., Kobayashi, S., Andrae, U., Balmaseda, M. A., Balsamo, G., Bauer, P., Bechtold, P., Beljaars, A. C. M., van de Berg, L., Bidlot, J., Bormann, N., Delsol, C., Dragani, R., Fuentes, M., Geer, A. J., Haimberger, L., Healy, S. B., Hersbach, H., Holm, E. V., Isaksen, L., Kallberg, P., Kohler, M., Matricardi, M., McNally, A. P., Monge-Sanz, B. M., Morcrette, J. J., Park, B. K., Peubey, C., de Rosnay, P., Tavolato, C., Thepaut, J. N., and Vitart, F.: The ERA-Interim reanalysis: configuration and performance of the data assimilation system, Q. J. Roy. Meteor. Soc., 137, 553-597, https://doi.org/10.1002/qj.828, 2011.

Dlugokencky, E. J., Hall, B. D., Montzka, S. A., Dutton, G., Muhle J., and Elkins, J. W.: Long-lived greenhouse gases, in: State of the Climate in 2017, Bull. Am. Meteorol. Soc., 99, Si-S310, https://doi.org/10.1175/2018BAMSStateoftheClimate.1, 2018.
Duncan, B. N., Logan, J. A., Bey, I., Megretskaia, I. A., Yantosca, R. M., Novelli, P. C., Jones, N. B., and Rinsland, C. P.: Global budget of CO, 1988-1997: Source estimates and validation with a global model, J. Geophys. Res., 112, D22301, https://doi.org/10.1029/2007JD008459, 2007.

Emmons, L. K., Schwantes, R. H., Orlando, J. J., Tyndall, G., Kinnison, D., Lamarque, J.-F., Marsh, D., Mills, M. J., Tilmes, S., Bardeen, C., Buchholz, R. R., Conley, A., Gettelman, A., Garcia, R., Simpson, I., Blake, D. R., Meinardi, S., and Pétron, G.: The Chemistry Mechanism in the Community Earth System Model Version 2 (CESM2), J. Adv. Model. Earth Sy., 12, e2019MS001882, https://doi.org/10.1029/2019MS001882, 2020.

Filipiak, M. J., Harwood, R. S., Jiang, J. H., Li, Q., Livesey, N. J., Manney, G. L., Read, W. G., Schwartz, M. J., Waters, J. W., and Wu, D. L.: Carbon monoxide measured by the EOS Microwave Limb Sounder on Aura: First results, Geophys. Res. Lett., 32, L14825, https://doi.org/10.1029/2005GL022765, 2005.

Fischer, H., Wienhold, F. G., Hoor, P., Bujok, O., Schiller, C., Siegmund, P., Ambaum, M., Scheeren, H. A., and Lelieveld, J.: Tracer correlations in the northern high latitude lowermost stratosphere: Influence of cross-tropopause mass exchange, Geophys. Res. Lett., 27, 97-100, https://doi.org/10.1029/1999GL010879, 2000.

Fu, R., Hu, Y., Wright, J. S., Jiang, J. H., Dickinson, R. E., Chen, M., Filipiak, M., Read, W. G., Waters, J. W., and $\mathrm{Wu}, \mathrm{D}$. L.: Short circuit of water vapor and polluted air to the global stratosphere by convective transport over the Tibetan Plateau, P. Natl. Acad. Sci. USA, 103, 5664-5669, https://doi.org/10.1073/pnas.0601584103, 2006.

Garcia, R. R. and Richter, J. H.: On the Momentum Budget of the Quasi-Biennial Oscillation in the Whole Atmosphere Community Climate Model, J. Atmos. Sci., 76, 69-87, https://doi.org/10.1175/JAS-D-18-0088.1, 2019.

Garny, H. and Randel, W. J.: Dynamic variability of the Asian monsoon anticyclone observed in potential vorticity and correlations with tracer distributions, J. Geophys. Res.-Atmos., 118, 1342113433, https://doi.org/10.1002/2013JD020908, 2013.

Garny, H. and Randel, W. J.: Transport pathways from the Asian monsoon anticyclone to the stratosphere, Atmos. Chem. Phys., 16, 2703-2718, https://doi.org/10.5194/acp-16-27032016, 2016.

German Aerospace Center: HALO database, available at: https:// halo-db.pa.op.dlr.de/mission/101, last access: 25 January 2021.

Gettelman, A., Hoor, P., Pan, L. L., Randel, W. J., Hegglin, M. I., and Birner, T.: The Extratropical Upper Troposphere and Lower Stratosphere, Rev. Geophys., 49, RG3003, https://doi.org/10.1029/2011RG000355, 2011.

Gettelman, A., Mills, M. J., Kinnison, D. E., Garcia, R. R., Smith, A. K., Marsh, D. R., Tilmes, S., Vitt, F., Bardeen, C. G., McInerny, J., Liu, H. L., Solomon, S. C., Polvani, L. M., Emmons, L. K., Lamarque, J. F., Richter, J. H., Glanville, A. S., Bacmeister, J. T., Phillips, A. S., Neale, R. B., Simpson, I. R., DuVivier, A. K., Hodzic, A., and Randel, W. J.: The Whole Atmosphere Community Climate Model Version 6 (WACCM6), J. Geophys. Res.-Atmos., 124, 12380-12403, https://doi.org/10.1029/2019JD030943, 2019. 
Gill, A. E.: Some simple solutions for heat-induced tropical circulation, Q. J. Roy. Meteorol. Soc., 106, 447-462, https://doi.org/10.1002/qj.49710644905, 1980.

Gottschaldt, K.-D., Schlager, H., Baumann, R., Bozem, H., Eyring, V., Hoor, P., Jöckel, P., Jurkat, T., Voigt, C., Zahn, A., and Ziereis, H.: Trace gas composition in the Asian summer monsoon anticyclone: a case study based on aircraft observations and model simulations, Atmos. Chem. Phys., 17, 6091-6111, https://doi.org/10.5194/acp-17-6091-2017, 2017.

Hintsa, E. J., Boering, K. A., Weinstock, E. M., Anderson, J. G., Gary, B. L., Pfister, L., Daube, B. C., Wofsy, S. C., Loewenstein, M., Podolske, J. R., Margitan, J. J., and Bui, T. P.: Troposphereto-stratosphere transport in the lowermost stratosphere from measurements of $\mathrm{H}_{2} \mathrm{O}, \mathrm{CO}_{2}, \mathrm{~N}_{2} \mathrm{O}$ and $\mathrm{O}_{3}$, Geophys. Res. Lett., 25, 2655-2658, https://doi.org/10.1029/98GL01797, 1998.

Holloway, T., Levy, H., and Kasibhatla, P.: Global distribution of carbon monoxide, J. Geophys. Res., 105, 12123-12147, https://doi.org/10.1029/1999JD901173, 2000.

Homan, C. D., Volk, C. M., Kuhn, A. C., Werner, A., Baehr, J., Viciani, S., Ulanovski, A., and Ravegnani, F.: Tracer measurements in the tropical tropopause layer during the AMMA/SCOUTO3 aircraft campaign, Atmos. Chem. Phys., 10, 3615-3627, https://doi.org/10.5194/acp-10-3615-2010, 2010.

Honomichl, S. B., Pan, L. L., and von Hobe, M.: WACCM simulated Carbon Monoxide (CO) in the Asian Summer Monsoon anticyclone during 2017 StratoClim campaign at different pressure levels, Copernicus Publications, TIB-Portal, https://doi.org/10.5446/48163, 2020.

Hoor, P., Fischer, H., Lange, L., Lelieveld, J., and Brunner, D.: Seasonal variations of a mixing layer in the lowermost stratosphere as identified by the $\mathrm{CO}-\mathrm{O}_{3}$ correlation from in situ measurements, J. Geophys. Res., 107, 4044, https://doi.org/10.1029/2000JD000289, 2002.

Hoor, P., Gurk, C., Brunner, D., Hegglin, M. I., Wernli, H., and Fischer, H.: Seasonality and extent of extratropical TST derived from in-situ CO measurements during SPURT, Atmos. Chem. Phys., 4, 1427-1442, https://doi.org/10.5194/acp-4-1427-2004, 2004.

Hoskins, B. J. and Rodwell, M. J.: A Model of the Asian Summer Monsoon. Part I: The Global Scale, J. Atmos. Sci., 52, 1329-1340, https://doi.org/10.1175/15200469(1995)052<1329:AMOTAS>2.0.CO;2, 1995.

Kloss, C., Tan, V., Leen, J. B., Madsen, G. L., Gardner, A., Du, X., Kulessa, T., Schillings, J., Schneider, J., Schrade, S., Qiu, C., and Von Hobe, M.: Airborne Mid-Infrared Cavity enhanced Absorption spectrometer (AMICA), Atmos. Meas. Tech., in preparation, 2021.

Konopka, P. and Pan, L. L.: On the mixing-driven formation of the Extratropical Transition Layer (ExTL), J. Geophys. Res., 117, D18301, https://doi.org/10.1029/2012JD017876, 2012.

Lau, W. K. M., Yuan, C., and Li, Z.: Origin, Maintenance and Variability of the Asian Tropopause Aerosol Layer (ATAL): The Roles of Monsoon Dynamics, Sci. Rep.-UK, 8, 3960, https://doi.org/10.1038/s41598-018-22267-z, 2018.

Lee, K.-O., Dauhut, T., Chaboureau, J.-P., Khaykin, S., Krämer, M., and Rolf, C.: Convective hydration in the tropical tropopause layer during the StratoClim aircraft campaign: pathway of an observed hydration patch, Atmos. Chem. Phys., 19, 11803-11820, https://doi.org/10.5194/acp-19-11803-2019, 2019.
Lee, K.-O., Barret, B., Flochmoën, E. L., Tulet, P., Bucci, S., von Hobe, M., Kloss, C., Legras, B., Leriche, M., Sauvage, B., Ravegnani, F., and Ulanovsky, A.: Convective uplift of pollution from the Sichuan basin into the Asian monsoon anticyclone during the StratoClim aircraft campaign, Atmos. Chem. Phys. Discuss. [preprint], https://doi.org/10.5194/acp-2020-581, in review, 2020.

Legras, B. and Bucci, S.: Confinement of air in the Asian monsoon anticyclone and pathways of convective air to the stratosphere during the summer season, Atmos. Chem. Phys., 20, 1104511064, https://doi.org/10.5194/acp-20-11045-2020, 2020.

Li, D., Vogel, B., Bian, J., Müller, R., Pan, L. L., Günther, G., Bai, Z., Li, Q., Zhang, J., Fan, Q., and Vömel, H.: Impact of typhoons on the composition of the upper troposphere within the Asian summer monsoon anticyclone: the SWOP campaign in Lhasa 2013, Atmos. Chem. Phys., 17, 4657-4672, https://doi.org/10.5194/acp-17-4657-2017, 2017.

Li, D., Vogel, B., Müller, R., Bian, J., Günther, G., Ploeger, F., Li, Q., Zhang, J., Bai, Z., Vömel, H., and Riese, M.: Dehydration and low ozone in the tropopause layer over the Asian monsoon caused by tropical cyclones: Lagrangian transport calculations using ERA-Interim and ERA5 reanalysis data, Atmos. Chem. Phys., 20, 4133-4152, https://doi.org/10.5194/acp20-4133-2020, 2020.

Li, Q., Jiang, J. H., Wu, D. L., Read, W. G., Livesey, N. J., Waters, J. W., Zhang, Y., Wang, B., Filipiak, M. J., Davis, C. P., Turquety, S., Wu, S., Park, R. J., Yantosca, R. M., and Jacob, D. J.: Convective outflow of South Asian pollution: A global CTM simulation compared with EOS MLS observations, Geophys. Res. Lett., 32, L14826, https://doi.org/10.1029/2005g1022762, 2005.

Marcy, T. P., Fahey, D. W., Gao, R. S., Popp, P. J., Richard, E. C., Thompson, T. L., Rosenlof, K. H., Ray, E. A., Salawitch, R. J., Atherton, C. S., Bergmann, D. J., Ridley, B. A., Weinheimer, A. J., Loewenstein, M., Weinstock, E. M., and Mahoney, M. J.: Quantifying stratospheric ozone in the upper troposphere with in situ measurements of $\mathrm{HCl}$, Science, 304, 261-265, https://doi.org/10.1126/science.1093418, 2004.

Munchak, L. A. and Pan, L. L.: Separation of the lapse rate and the cold point tropopauses in the tropics and the resulting impact on cloud top-tropopause relationships, J. Geophys. Res., 119, 7963 7978, https://doi.org/10.1002/2013jd021189, 2014.

Nash, E. R., Newman, P. A., Rosenfield, J. E., and Schoeberl, M. R.: An objective determination of the polar vortex using Ertel's potential vorticity, J. Geophys. Res., 101, 9471-9478, https://doi.org/10.1029/96JD00066, 1996.

Nützel, M., Podglajen, A., Garny, H., and Ploeger, F.: Quantification of water vapour transport from the Asian monsoon to the stratosphere, Atmos. Chem. Phys., 19, 8947-8966, https://doi.org/10.5194/acp-19-8947-2019, 2019.

O'Keefe, A., Scherer, J. J., and Paul, J. B.: cw Integrated cavity output spectroscopy, Chem. Phys. Lett., 307, 343-349, https://doi.org/10.1016/S0009-2614(99)00547-3, 1999.

Pan, L. L., Bowman, K. P., Shapiro, M., Randel, W. J., Gao, R. S., Campos, T., Davis, C., Schauffler, S., Ridley, B. A., Wei, J. C., and Barnet, C.: Chemical behavior of the tropopause observed during the Stratosphere-Troposphere Analyses of Regional Transport experiment, J. Geophys. Res., 112, D18305, https://doi.org/10.1029/2012JD017695, 2007. 
Pan, L. L., Bowman, K. P., Atlas, E. L., Wofsy, S. C., Zhang, F. Q., Bresch, J. F., Ridley, B. A., Pittman, J. V., Homeyer, C. R., Romashkin, P., and Cooper, W. A.: The Stratosphere-Troposphere Analyses of Regional Transport 2008 Experiment, B. Am. Meteorol. Soc., 91, 327-342, https://doi.org/10.1175/2009BAMS2865.1, 2010.

Pan, L. L., Honomichl, S. B., Kinnison, D. E., Abalos, M., Randel, W. J., Bergman, J. W., and Bian, J.: Transport of chemical tracers from the boundary layer to stratosphere associated with the dynamics of the Asian summer monsoon, J. Geophys. Res.-Atmos., 121, 14159-14174, https://doi.org/10.1002/2016JD025616, 2016.

Pan, L. L., Honomichl, S. B., Bui, T. V., Thornberry, T., Rollins, A., Hintsa, E., and Jensen, E. J.: Lapse Rate or Cold Point: The Tropical Tropopause Identified by In Situ Trace Gas Measurements, Geophys. Res. Lett., 45, 10756-10763, https://doi.org/10.1029/2018GL079573, 2018.

Pan, L. L., Honomichl, S. B., Thornberry, T., Rollins, A., Bui, T. P., Pfister, L., and Jensen, E. E.: Observational Evidence of Horizontal Transport-Driven Dehydration in the TTL, Geophys. Res. Lett., 46, 7848-7856, https://doi.org/10.1029/2019GL083647, 2019.

Park, M., Randel, W. J., Gettelman, A., Massie, S. T., and Jiang, J. H.: Transport above the Asian summer monsoon anticyclone inferred from Aura Microwave Limb Sounder tracers, J. Geophys. Res., 112, D16309, https://doi.org/10.1029/2006JD008294, 2007.

Park, M., Randel, W. J., Emmons, L. K., Bernath, P. F., Walker, K. A., and Boone, C. D.: Chemical isolation in the Asian monsoon anticyclone observed in Atmospheric Chemistry Experiment (ACE-FTS) data, Atmos. Chem. Phys., 8, 757-764, https://doi.org/10.5194/acp-8-757-2008, 2008.

Park, M., Randel, W. J., Emmons, L. K., and Livesey, N. J.: Transport pathways of carbon monoxide in the Asian summer monsoon diagnosed from Model of Ozone and Related Tracers (MOZART), J. Geophys. Res., 114, D08303, https://doi.org/10.1029/2008JD010621, 2009.

Ploeger, F., Konopka, P., Müller, R., Fueglistaler, S., Schmidt, T., Manners, J. C., Grooß, J.-U., Günther, G., Forster, P. M., and Riese, M.: Horizontal transport affecting trace gas seasonality in the Tropical Tropopause Layer (TTL), J. Geophys. Res., 117, D09303, https://doi.org/10.1029/2011JD017267, 2012.

Ploeger, F., Gottschling, C., Griessbach, S., Grooß, J.-U., Guenther, G., Konopka, P., Müller, R., Riese, M., Stroh, F., Tao, M., Ungermann, J., Vogel, B., and von Hobe, M.: A potential vorticitybased determination of the transport barrier in the Asian summer monsoon anticyclone, Atmos. Chem. Phys., 15, 13145-13159, https://doi.org/10.5194/acp-15-13145-2015, 2015.

Ploeger, F., Konopka, P., Walker, K., and Riese, M.: Quantifying pollution transport from the Asian monsoon anticyclone into the lower stratosphere, Atmos. Chem. Phys., 17, 7055-7066, https://doi.org/10.5194/acp-17-7055-2017, 2017.

Randel, W. J. and Park, M.: Deep convective influence on the Asian summer monsoon anticyclone and associated tracer variability observed with Atmospheric Infrared Sounder (AIRS), J. Geophys. Res., 111, D12314, https://doi.org/10.1029/2005JD006490, 2006.

Randel, W. J., Park, M., Emmons, L., Kinnison, D., Bernath, P., Walker, K. A., Boone, C., and Pumphrey, H.: Asian Monsoon
Transport of Pollution to the Stratosphere, Science, 328, 611613, https://doi.org/10.1126/science.1182274, 2010.

Rothman, L. S., Gordon, I. E., Babikov, Y., Barbe, A., Benner, D. C., Bernath, P. F., Birk, M., Bizzocchi, L., Boudon, V., Brown, L. R., Campargue, A., Chance, K., Cohen, E. A., Coudert, L. H., Devi, V. M., Drouin, B. J., Fayt, A., Flaud, J. M., Gamache, R. R., Harrison, J. J., Hartmann, J. M., Hill, C., Hodges, J. T., Jacquemart, D., Jolly, A., Lamouroux, J., Le Roy, R. J., Li, G., Long, D. A., Lyulin, O. M., Mackie, C. J., Massie, S. T., Mikhailenko, S., Muller, H. S. P., Naumenko, O. V., Nikitin, A. V., Orphal, J., Perevalov, V., Perrin, A., Polovtseva, E. R., Richard, C., Smith, M. A. H., Starikova, E., Sung, K., Tashkun, S., Tennyson, J., Toon, G. C., Tyuterev, V. G., and Wagner, G.: The HITRAN2012 molecular spectroscopic data base, J. Quant. Spectrosc. Ra., 130, 4-50, https://doi.org/10.1016/j.jqsrt.2013.07.002, 2013.

Santee, M. L., Manney, G. L., Livesey, N. J., Schwartz, M. J., Neu, J. L., and Read, W. G.: A comprehensive overview of the climatological composition of the Asian summer monsoon anticyclone based on 10 years of Aura Microwave Limb Sounder measurements, J. Geophys. Res.-Atmos., 122, 54915514, https://doi.org/10.1002/2016JD026408, 2017.

Schoeberl, M. R., Dessler, A. E., and Wang, T.: Simulation of stratospheric water vapor and trends using three reanalyses, Atmos. Chem. Phys., 12, 6475-6487, https://doi.org/10.5194/acp12-6475-2012, 2012.

SPARC Report on the Lifetimes of Stratospheric Ozone-Depleting Substances, Their Replacements, and Related Species, edited by: Ko, M., Newman, P., Reimann, S., and Strahan, S., SPARC Report No. 6, WCRP-15/2013, 2013.

Stroh, F., Müller, R., Legras, B., Nützel, M., Dameris, M., Vogel, B., Bucci, S., Khaykin, S., Brunamonti, S., Peter, T., Plöger, F., Borrmann, S., Cairo, F., Schlager, H., Afchine, A., Belyaev, G., Brühl, C., D’Amato, F., Dragoneas, A., Ebert, M., Fadnavis, S., Fierli, F., Friedl-Vallon, F., Fugal, J., Grooß, J.-U., Höpfner, M., Johansson, S., Karmacharya, J., Kloss, C., Konopka, P., Krämer, M., Laube, J., Lehmann, R., Luo, B., Lykov, A., Mahnke, C. O., Mitev, V., Molleker, S., Moyer, E., Oelhaf, H., Pokharel ,J., Preusse, P., Ravegnani, F., Riese, M., Röckmann, T., Rolf, C., Santee, M., Spelten, N., Stiller, G., Stratmann, G., Ulanovski, A., Ungermann, J., Viciani, S., Volk, C.M., von der Gathen, P., von Hobe, M., Weigel, R., Wohltmann, I., Yushkov, V., and Rex, M.: First detailed airborne and balloon measurements of microphysical, dynamical and chemical processes in the Asian Summer Monsoon Anticyclone: Overview and First Results of the 2016/17 StratoClim field campaigns, Atmos. Chem. Phys., in preparation, 2021.

Tao, M., Konopka, P., Ploeger, F., Yan, X., Wright, J. S., Diallo, M., Fueglistaler, S., and Riese, M.: Multitimescale variations in modeled stratospheric water vapor derived from three modern reanalysis products, Atmos. Chem. Phys., 19, 6509-6534, https://doi.org/10.5194/acp-19-6509-2019, 2019.

Thomason, L. W. and Vernier, J.-P.: Improved SAGE II cloud/aerosol categorization and observations of the Asian tropopause aerosol layer: 1989-2005, Atmos. Chem. Phys., 13, 4605-4616, https://doi.org/10.5194/acp-13-4605-2013, 2013.

Ueyama, R., Jensen, E. J., and Pfister, L.: Convective Influence on the Humidity and Clouds in the Tropical Tropopause Layer During Boreal Summer, J. Geophys. Res.-Atmos., 123, 7576-7593, https://doi.org/10.1029/2018JD028674, 2018. 
Ulanovsky, A. E., Yushkov, V. A., Sitnikov, N. M., and Ravegnani, F.: The FOZAN-II fast-response chemiluminescent airborne ozone analyzer, Instrum. Exp. Tech+., 44, 249-256, 2001.

US National Science Foundation: CESM2 (CESM2.1), available at: https://escomp.github.io/CESM/versions/cesm2.1/html/ downloading_cesm.html, (last access: 25 January 2021), 2020.

Vernier, J. P., Thomason, L. W., and Kar, J.: CALIPSO detection of an Asian tropopause aerosol layer, Geophys. Res. Lett., 38, L07804, https://doi.org/10.1029/2010GL046614, 2011.

Vogel, B., Pan, L. L., Konopka, P., Günther, G., Müller, R., Hall, W., Campos, T., Pollack, I., Weinheimer, A., Wei, J., Atlas, E. L., and Bowman, K. P.: Transport pathways and signatures of mixing in the extratropical tropopause region derived from Lagrangian model simulations, J. Geophys. Res., 116, D05306, https://doi.org/10.1029/2010JD014876, 2011.

Vogel, B., Günther, G., Müller, R., Grooß, J.-U., and Riese, M.: Impact of different Asian source regions on the composition of the Asian monsoon anticyclone and of the extratropical lowermost stratosphere, Atmos. Chem. Phys., 15, 13699-13716, https://doi.org/10.5194/acp-15-13699-2015, 2015.

Vogel, B., Müller, R., Günther, G., Spang, R., Hanumanthu, S., Li, D., Riese, M., and Stiller, G. P.: Lagrangian simulations of the transport of young air masses to the top of the Asian monsoon anticyclone and into the tropical pipe, Atmos. Chem. Phys., 19, 6007-6034, https://doi.org/10.5194/acp-19-6007-2019, 2019.

Wiedinmyer, C., Akagi, S. K., Yokelson, R. J., Emmons, L. K., AlSaadi, J. A., Orlando, J. J., and Soja, A. J.: The Fire INventory from NCAR (FINN): a high resolution global model to estimate the emissions from open burning, Geosci. Model Dev., 4, 625641, https://doi.org/10.5194/gmd-4-625-2011, 2011.

WMO: Meteorology - A three dimensional science: Second session of the Commission for Aerology, WMO Bulletin, IV, 134-138, 1957.
Wright, J. S. and Fueglistaler, S.: Large differences in reanalyses of diabatic heating in the tropical upper troposphere and lower stratosphere, Atmos. Chem. Phys., 13, 9565-9576, https://doi.org/10.5194/acp-13-9565-2013, 2013.

Xiao, Y. P., Jacob, D. J., and Turquety, S.: Atmospheric acetylene and its relationship with $\mathrm{CO}$ as an indicator of air mass age, J. Geophys. Res.-Atmos., 112, D12305, https://doi.org/10.1029/2006JD008268,2007.

Yan, X., Konopka, P., Ploeger, F., Podglajen, A., Wright, J. S., Müller, R., and Riese, M.: The efficiency of transport into the stratosphere via the Asian and North American summer monsoon circulations, Atmos. Chem. Phys., 19, 15629-15649, https://doi.org/10.5194/acp-19-15629-2019, 2019.

Yu, P., Rosenlof, K. H., Liu, S., Telg, H., Thornberry, T. D., Rollins, A. W., Portmann, R. W., Bai, Z., Ray, E. A., Duan, Y., Pan, L. L., Toon, O. B., Bian, J., and Gao, R.-S.: Efficient transport of tropospheric aerosol into the stratosphere via the Asian summer monsoon anticyclone, P. Natl. Acad. Sci. USA, 114, 6972-6977, 2017.

Yuan, C., Lau, W. K. M., Li, Z., and Cribb, M.: Relationship between Asian monsoon strength and transport of surface aerosols to the Asian Tropopause Aerosol Layer (ATAL): interannual variability and decadal changes, Atmos. Chem. Phys., 19, 19011913, https://doi.org/10.5194/acp-19-1901-2019, 2019.

Yushkov, V., Oulanovsky, A., Lechenuk, N., Roudakov, I., Arshinov, K., Tikhonov, F., Stefanutti, L., Ravegnani, F., Bonafe, U., and Georgiadis, T.: A chemiluminescent analyzer for stratospheric measurements of the ozone concentration (FOZAN), J. Atmos. Ocean. Tech., 16, 1345-1350, 1999. 